\title{
A EMIGRAÇÃO PORTUGUESA NO SÉCULO XXI
}

\author{
Rui Pena Pires
}

Iscte - Instituto Universitário de Lisboa, Centro de Investigação e Estudos de Sociologia (CIES-Iscte), Observatório da Emigração, Lisboa, Portugal

\section{Cláudia Pereira}

Iscte - Instituto Universitário de Lisboa, Centro de Investigação e Estudos de Sociologia (CIES-Iscte), Observatório da Emigração, Lisboa, Portugal

\section{Joana Azevedo}

Iscte - Instituto Universitário de Lisboa, Centro de Investigação e Estudos de Sociologia (CIES-Iscte), Observatório da Emigração, Lisboa, Portugal

\section{Inês Vidigal}

Iscte - Instituto Universitário de Lisboa, Centro de Investigação e Estudos de Sociologia (CIES-Iscte), Observatório da Emigração, Lisboa, Portugal

\section{Carlota Moura Veiga}

Iscte - Instituto Universitário de Lisboa, Centro de Investigação e Estudos de Sociologia (CIES-Iscte), Observatório da Emigração, Lisboa, Portugal

Resumo A emigração portuguesa cresceu nas vésperas do 25 de Abril, regrediu para níveis mínimos depois daquela data, voltou a crescer a partir de meados dos anos 80 , acentuou-se no início do novo século, reduziu-se na crise financeira de 2008, atingiu de novo máximos históricos em 2013 e voltou a diminuir, lentamente, desde então. Em termos comparados, Portugal é hoje um país de repulsão migratória, característica que partilha com a maioria dos estados do Leste europeu. Neste artigo, apresentamos a história recente da emigração portuguesa, identificamos os mecanismos e episódios que a explicam e discutimos os problemas metodológicos envolvidos no seu estudo.

Palavras-chave: emigração portuguesa, migrações intraeuropeias, crise e migrações, indicadores das migrações.

Portuguese emigration in the 21st century

Abstract Portuguese emigration grew on the eve of the 25th of April, regressed to minimum levels after that date, increased again from the mid-1980s, became more accentuated at the beginning of the new century, decreased in the financial crisis of 2008, reached new historical highs in 2013 and has slowly declined since then. In comparative terms, Portugal is today a country of migratory repulsion, a characteristic that it shares with most Eastern European states. In this article, we present the recent history of Portuguese emigration, identify the mechanisms and episodes that explain it and discuss the methodological problems involved in its study.

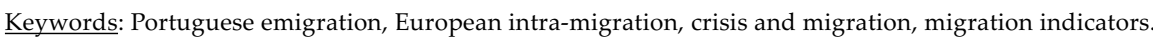

L'émigration portugaise au 21e siècle

Résumé L'émigration portugaise a augmenté à la veille du 25 Avril, a régressé au minimum après cette date, a augmenté à nouveau à partir du milieu des années 80 , s'est accentuée au début du nouveau siècle, s'est atténuée lors de la crise financière de 2008, a atteint de nouveaux sommets historiques en 2013 et a lentement diminué depuis lors. En termes comparatifs, le Portugal est aujourd'hui un pays de répulsion migratoire, une caractéristique qu'il partage avec la plupart des Etats d'Europe de l'Est. Dans cet article, nous présentons l'histoire récente de l'émigration portugaise, identifions les mécanismes et épisodes qui l'expliquent et discutons des problèmes méthodologiques impliqués dans son étude.

Mots-clés: émigration portugaise, migration intra-européenne, crise et migration, indicateurs de migration. 
Resumen La emigración portuguesa creció en la víspera del 25 de Abril, retrocedió a niveles mínimos después de esa fecha, aumentó nuevamente desde mediados de la década de 1980, se acentuó más a principios del nuevo siglo, disminuyó en la crisis financiera de 2008, alcanzó nuevos máximos históricos en 2013 y ha disminuido lentamente desde entonces. En términos comparativos, Portugal es hoy un país de repulsión migratoria, una característica que comparte con la mayoría de los estados de Europa del Este. En este artículo, presentamos la historia reciente de la emigración portuguesa, identificamos los mecanismos y episodios que lo explican y discutimos los problemas metodológicos involucrados en su estudio.

Palabras-clave: emigración portuguesa, migración intraeuropea, crisis y migración, indicadores de migración.

... uma teoria sólida só prospera com uma dieta rica em factos pertinentes...

(Merton, 1970 [1968]: 181)

Nos anos que se seguiram ao 25 de Abril de 1974, mudou radicalmente o padrão das migrações internacionais de e para Portugal. A emigração, que tinha atingido o seu pico pouco antes, em 1970, ano em que saíram do país mais de 180 mil pessoas, foi bruscamente interrompida, demorando alguns anos a retomar uma lenta trajetória ascendente. A imigração, até então um fenómeno praticamente desconhecido em Portugal, irrompeu subitamente com o repatriamento de África de meio milhão de portugueses no curto prazo de um ano. Na sequência deste episódio, e com ele relacionado, iniciou-se e cresceu, sobretudo até finais da década de 1980, uma imigração africana pós-colonial. A esta seguiram-se e somaram-se outros fluxos, da União Europeia e do Brasil, primeiro, e do Leste europeu, no final do século XX. Já na segunda década do século XXI, iniciou-se um crescimento de fluxos com pouca expressão no passado, sobretudo a partir da China e de países da Ásia do Sul (Índia, Paquistão, Bangladesh, Nepal). Em resumo, emigração e imigração cresceram de forma continuada a partir dos anos 80 , a segunda mais do que a primeira, em particular desde a adesão de Portugal à então Comunidade Económica Europeia, em 1986. Na viragem do século, a imigração atingiu os valores máximos da sua curta história, a que se seguiu uma fase de diminuição continuada, ao mesmo tempo que o crescimento da emigração acelerou para níveis próximos dos finais da década de 1960, atingindo um novo pico em 2013, com 120 mil saídas. A partir daí, a emigração iniciou uma trajetória de descida gradual, a par com a progressiva retoma da imigração. ${ }^{1}$

O que explica estas variações? É frequente argumentar-se que as migrações, em geral, e a emigração portuguesa, em particular, são o resultado de desigualdades socioespaciais persistentes. Seja nas teorias económicas das migrações de trabalho de inspiração neoclássica, seja nas teorias do sistema-mundo, a tese pode ser resumida em termos muito simples: as migrações tendem a dirigir-se de países menos

1 Sobre a história das migrações internacionais de e para Portugal no século XX, este artigo segue de perto as sínteses disponíveis em Peixoto (2000), para a emigração, e em Pires (2003), para a imigração, incluindo o repatriamento de África. 
desenvolvidos, ou periféricos, para países mais desenvolvidos, ou centrais. Os mecanismos que sustentam essa mobilidade e a sua direção são diferentes nas teorias em causa, mas o resultado é o mesmo: por interesse de atores racionais ou por pressões estruturais, a desigualdade territorial gera migrações num sentido particular. A explicação não é falsa, embora seja parcial, e os mecanismos alternativos em que se sustenta fazem, ambos, sentido. No que tem de verdadeiro é, porém, insuficiente.

Insuficiente, desde logo, para explicar as variações observáveis nos fluxos migratórios. Em termos relativos, Portugal é, no contexto europeu, um país menos desenvolvido ou periférico, hoje como nos anos 60 . O crescimento da economia nos anos da EFTA e o desenvolvimento pós-25 de Abril foram reais e tiveram consequências: ${ }^{2}$ Portugal faz parte do reduzido grupo de países de desenvolvimento humano muito elevado (United Nations Development Programme, 2019:300). Porém, persiste o hiato em relação aos países europeus mais desenvolvidos, mesmo tendo diminuído entre o início dos anos 60 e meados dos 90, mantendo-se Portugal na periferia da Europa. E Portugal é, também, um país em que, desde o início do século $X X$, a emigração já foi muito elevada, tanto quando o crescimento da economia foi também elevado como quando foi reduzido ou mesmo negativo, quase desapareceu, retomou lentamente, cresceu subitamente ou desacelerou, por mais de uma vez. Ora, uma constante, ainda que tendencial, o menor desenvolvimento relativo português, não pode explicar uma variação, neste caso a grande variação dos fluxos de emigração.

Em geral, as assimetrias de desenvolvimento podem criar um potencial de emigração, mas não garantem a efetivação desse potencial. Informação imperfeita, custos de insegurança resultantes da desrotinização induzida pela mobilidade, barreiras internacionais à livre circulação são alguns dos obstáculos que bloqueiam a resposta generalizada à desigualdade socioespacial por via das migrações. Por isso, as migrações internacionais são, ainda hoje, um fenómeno globalmente minoritário, que envolve menos de $4 \%$ da população mundial, apesar das persistentes desigualdades globais. ${ }^{3}$

Sabemos, também, que a constituição de redes migratórias permite reduzir parte daqueles custos. As redes sociais entre migrantes e entre estes e os seus círculos de pertença presentes e anteriores, nos países de destino e de origem, são estruturas de circulação de informação, de confiança e de recursos materiais e culturais que facilitam a transformação do potencial migratório em realidade migratória. Como fatores geradores de migrações as redes só operam, porém, no médio prazo. A razão é lapaliciana. Para haver redes migratórias tem que haver migrações, pelo que, no curto prazo, as

2 EFTA: European Free Trade Association (em português, Associação Europeia de Comércio Livre). Portugal pertenceu à EFTA entre janeiro de 1960 e 1986. A organização integrou ainda a Suécia, o Reino Unido, a Dinamarca, a Noruega, a Suíça, a Áustria, a Islândia e o Liechtenstein. Hoje reúne apenas quatro países (Suíça, Liechtenstein, Noruega e Islândia) e tem acordos de livre circulação de pessoas e bens com a União Europeia.

3 United Nations, DESA, Population Division: International Migrant Stock: The 2019 Revision (https://www.un.org/en/development/desa/population/migration/index.asp). Dizer que nas migrações internacionais está envolvida menos de $4 \%$ da população mundial significa dizer que se estima que $4 \%$ da população mundial é composta por indivíduos que vivem num país diferente daquele em que nasceram. 
redes são consequência e não causa destas. Uma vez estabelecidas, as redes migratórias são estruturas fundamentais na reprodução e ampliação dos fenómenos migratórios, mas não os iniciam (Faist, 2000). Já a partir do momento em que ganham escala e continuidade, as migrações são suportadas por redes e, simultaneamente, criam, ampliam e reproduzem redes (Goldin, Cameron e Blarajan, 2011: 104).

Este dilema explicativo não é específico do domínio das migrações. Em regra, é aconselhável separar a análise e explicação da génese dos fenómenos sociais da análise e explicação da sua reprodução. E, com frequência, a génese deve ser procurada num tipo particular de causalidade singular, histórica, por contraponto à causalidade geral operante em fenómenos repetidos caracterizados pela regularidade das suas dinâmicas. Em resumo, a causalidade genética é, em regra, no plano social, a causalidade dos acontecimentos, não a das regularidades, ou a dos condicionamentos estruturais, que, no entanto, explicam melhor a reprodução dos fenómenos gerados por aqueles acontecimentos. ${ }^{4}$ Por isso, faz sentido distinguir entre teorias ou explicações da iniciação das migrações e teorias ou explicações da reprodução das migrações, como tem sido sugerido (Massey et al., 1993).

Os fatores estruturais, no plano das assimetrias e das desigualdades do desenvolvimento, constituem um potencial de emigração que, em Portugal, como na generalidade dos países, se traduzem em emigração efetiva quando irrompem episódios críticos, no sentido sociológico do termo (Giddens, 1984: 61; Giddens, 1994 [1991]: 100-102), que potenciam ou viabilizam esse potencial. Explicar as variações da emigração portuguesa passa, por isso, pela identificação daqueles episódios na história recente do país e do seu contexto internacional. Episódios que podem impactar diretamente nos emigrantes potenciais, ou indiretamente, através da ação de organizações formais e informais, públicas ou privadas, de recrutamento no destino ou de promoção na origem.

$\mathrm{Na}$ análise que segue, procuramos identificar os efeitos, nas dinâmicas da emigração portuguesa, quer dos episódios críticos que as constituem, aceleram ou travam, quer das redes migratórias que sustentam a evolução dos fluxos induzidos por tais episódios. Para o efeito usamos, sobretudo, dados compilados, sistematizados, analisados e disponibilizados pelo Observatório da Emigração. ${ }^{5}$ Dez anos depois de ter iniciado a sua atividade, em 2009, o Observatório disponibiliza hoje, em acesso livre, um conjunto de informação de base que pode sustentar estudos

4 A distinção entre causalidade singular e geral é inspirada, embora não a reproduza, na distinção weberiana entre causas acidentais e causas necessárias (ver Pires, 2015). Sobre a causalidade enquanto produto de acontecimentos singulares ver Weber (1905 [1949]); sobre o conceito de regularidades causais no sentido em que é usado neste texto, ver Demeulenaere (2011). Sobre o tipo de relação recursiva entre redes e migrações, ver o conceito de causalidade cumulativa, inicialmente apresentado por Myrdal (1957).

5 Observatório da Emigração: www.observatorioemigracao.pt. O presente artigo faz uso não só dos dados compilados pelo Observatório, como de muitos dos resultados da análise desses dados pela sua equipa de investigadores, resultados esses apresentados em publicações disponibilizadas também em acesso livre no sítio eletrónico do Observatório. Entre essas publicações são recorrentemente usados ao longo do artigo: Pires et al. (2014); Pires et al. (2015); e Pires et al. (2019). Duas primeiras explorações sistemáticas dos dados e publicações do Observatório, também recorrentemente usadas, estão disponíveis em Pereira e Azevedo (2019a) e Pires (2019). 
sobre a emigração portuguesa, seja de âmbito geral, como o que a seguir se apresenta, seja de âmbito mais específico espacial e temporalmente. ${ }^{6}$

\section{Tendências}

Como se referiu, a emigração portuguesa, que teve um pico entre 1969 e 1973, foi interrompida em 1974. Para isso concorreram fatores comuns a um conjunto de países e fatores específicos do caso português. Entre os fatores comuns está a mudança das políticas migratórias em países de destino como a França e a Alemanha que, em resposta à crise económica de 1973, adotaram medidas restritivas opostas às que tinham posto em prática nas décadas anteriores. Nos fatores específicos estão os efeitos do 25 de Abril que gerou expetativas elevadas de mudanças na sociedade portuguesa, em especial de um desenvolvimento rápido e mais igualitário. Ora, parte da emigração imediatamente anterior para a Europa e África era não só um modo de escapar a situações de pobreza persistente como a expressão de falta de expetativas de mudança local que permitissem uma melhoria das condições de vida no país. Era, em termos sintéticos, uma variante do "voto com os pés" (Tiebout, 1956): se as condições não melhoram e sou colocado numa situação que me torna incapaz de fazer a diferença para que essa melhoria ocorra, se não tenho nem condições nem voz, a saída pode ser a melhor solução (Hirschman, 1970).

O 25 de Abril não se traduziu, de imediato, numa melhoria substancial das condições de vida da maioria da população, mas traduziu-se, no imediato, no incremento das expetativas de que essa melhoria era possível e dependia, pelo menos em parte, da voz que os portugueses tinham passado a ter. Traduziu-se, ainda, na eliminação dos fatores políticos de parte da emigração: a repressão estatal e a guerra colonial. Mudança política em Portugal e mudanças nas políticas migratórias nos países de destino tiveram, combinadas, um efeito de contração da emigração na segunda metade da década de 1970.

Como se referiu, a emigração retomaria uma trajetória de crescimento continuado a partir dos anos 80, em particular desde a integração europeia, em 1986. Essa retoma foi de início lenta e dirigida tanto para novos destinos como para os destinos europeus da fase anterior: a Suíça, logo desde 1979 (Marques, 2016), a Alemanha, nos anos da reconstrução que se seguiram à queda do Muro de Berlim, com um pico em 1996 (Candeias, 2017), e, já no século XXI, a Espanha primeiro (Pinho e Pires, 2013), a França e o Reino Unido num segundo momento (Marques et al., 2016; Góis et al., 2016).

No final da segunda década do século XXI, a emigração portuguesa, continuando mais concentrada naqueles destinos, generalizou-se a praticamente todos os

6 Apesar de toda a informação já recolhida e disponibilizada pelo Observatório, há, ainda, lacunas importantes que importa colmatar nos próximos anos de atividade deste organismo. Importa, por exemplo, tentar construir indicadores regionais, subnacionais, sobre as origens e destinos da emigração, bem como caracterizar, em termos sociodemográficos, os fluxos de emigração. 
países mais desenvolvidos da Europa. Em contrapartida, os fluxos intercontinentais para a América e África diminuíram, ficando reduzidos a valores mínimos. As poucas exceções dignas de registo a este padrão são o crescimento das saídas para Angola e Moçambique nos primeiros anos do século XXI, apesar de tudo com valores absolutos comparativamente modestos. Estes foram os únicos países não europeus entre os dez principais destinos da emigração portuguesa nos últimos anos para os quais há dados com um mínimo de fiabilidade. Ou seja, a emigração portuguesa, como outras migrações no mundo contemporâneo, regionalizou-se (Wihtol de Wenden, 2018), sendo hoje um fenómeno sobretudo europeu.

Em rigor, esta europeização tinha já sido iniciada na segunda metade dos anos 60 do século XX. Por um lado, estabilizaram-se ou reduziram-se, nessa altura, os fluxos migratórios para o continente americano, em especial para o Brasil e a Venezuela, a sul, e os EUA e o Canadá, a norte. Por outro, cresceram, na última fase do Estado Novo, os fluxos para as então colónias africanas de Angola e Moçambique, promovidos pelo Estado Novo como parte da sua estratégia de resposta à guerra de libertação nacional (Castelo, 2007), bem como, em maior escala, para a Europa desenvolvida, em especial para França, Alemanha e Luxemburgo. Para essa concentração de destinos europeus foi influente a combinação de dois fatores. Por um lado, as políticas de captação de migrantes postas em prática naqueles países de destino, envolvidos em processos de reconstrução e desenvolvimento no pós-II Guerra e com carências de mão-de-obra nos setores mais intensivos em trabalho, na indústria e na construção (Castles, de Haas e Miller, 2014). Por outro lado, o facto de o regime do Estado Novo ter iniciado uma política mais restritiva de saídas, só possível no quadro de limitação das liberdades à época, política que não travou a emigração mas se traduziu no crescimento da sua componente designada como "clandestina", feita por terra e, portanto, mais fácil para destinos de proximidade do que de longa distância, tendo em conta a escala em causa. Entre 1969 e 1973, emigraram cerca de meio milhão de portugueses, a quase totalidade dos quais para destinos europeus. A chamada emigração clandestina representou mais de $60 \%$ da emigração total e mais de três quartos da emigração intraeuropeia (Baganha e Marques, 2001).

No pós-25 de Abril, a progressiva concentração da emigração no espaço europeu representou, simplesmente, a resposta racional à progressiva ampliação das possibilidades de mobilidade no quadro europeu, sem as barreiras políticas, fronteiriças, existentes nas rotas para países terceiros. O resultado dessas novas possibilidades de mobilidade e a consequente redução de fluxos transcontinentais com uma história antiga não foram uma especificidade portuguesa. Por exemplo, é possível verificar, com os dados disponíveis, que a diminuição da emigração portuguesa para o Canadá se inscreveu num processo mais amplo de declínio das origens europeias dos migrantes entrados naquele país (Vidigal, 2018).

A progressiva facilitação da circulação de pessoas no espaço europeu, bem como nos países da EFTA com que foram estabelecidos acordos para o efeito - que culminaria na assinatura do acordo de Schengen, que Portugal subscreveria em 1991 - explica o crescente predomínio das escolhas de destinos europeus entre os emigrantes portugueses. A emigração europeia podia, ainda, tirar partido das redes 
migratórias latentes construídas no período anterior, ao contrário do que acontecia com o destino africano: neste caso, as redes tinham sido desfeitas com o repatriamento quase total da população das ex-colónias de origem europeia em 1975.

Em 2010/11, a nova realidade europeia da emigração estava já consolidada. Não só residiam no conjunto dos países europeus mais de dois terços dos portugueses emigrados como se dirigiram para a Europa mais de $85 \%$ dos emigrantes que, em 2010, sairam de Portugal. Dos restantes portugueses emigrados, 30\% viviam na América do Norte e do Sul, e apenas 3\% no resto do mundo. Em termos acumulados, o stock de emigrantes nascidos em Portugal a residir na Europa passou de $16 \%$ do total, em 1960, para $67 \%$, em 2010 . No mesmo período, o número total de emigrantes nascidos em Portugal a residir no estrangeiro duplicou, enquanto o número dos que residiam na Europa multiplicou por mais de nove, passando de 165 mil, em 1960, para mais de milhão e meio, em 2010/11 (ver figura 1$).^{7}$

A concentração na Europa foi, sobretudo, concentração na União Europeia e nos países do espaço económico europeu. De acordo com os dados dos censos nacionais de 2010/11, residiam nos países da UE e EFTA mais de 1,1 milhões de portugueses. França, Luxemburgo e, em menor grau, Alemanha, destacavam-se então entre os antigos países da emigração portuguesa. Suíça, Reino Unido e Espanha nos novos destinos. Entre os censos de 2000/01 e de 2010/11 aumentou substancialmente a população portuguesa emigrada nestes países. Naqueles em que viviam mais portugueses emigrados, esse crescimento variou entre cerca de $6 \%$ em França, e mais de $150 \%$, no Reino Unido. Crescimentos intermédios foram observados no Luxemburgo (+46\%), Suíça (+68\%) e Espanha (+76\%). Em termos absolutos, os crescimentos mais significativos ocorreram na população emigrada na Suíça (mais 68 mil indivíduos nascidos em Portugal), no Reino Unido (mais 56 mil), Espanha (mais 43 mil), França (mais 36 mil) e Luxemburgo (mais 19 mil).

Em sentido oposto, fora da Europa, países como o Brasil, a Venezuela, os EUA e o Canadá viram diminuir as populações de emigrantes portugueses, de fixação mais antiga. Essa diminuição, medida em termos relativos, foi maior no Brasil $(-35 \%)$ e na Venezuela (-30\%), e menos intensa nos EUA (-12\%) e no Canadá (-9\%). Em termos absolutos, em 2010/11 havia menos 131 mil emigrantes portugueses a viver nestes quatro países americanos do que em 2000/01 (ver quadro 1).

7 O estudo estatístico da emigração trabalha com dois conjuntos fundamentais de dados. Por um lado, dados de fluxos, isto é, do movimento de entradas e saídas de migrantes nos países de destino. Em regra, estes dados têm origem administrativa, periodicidade anual e definem como migrantes os estrangeiros que entraram num determinado país para aí residirem durante um ano ou mais. Por outro lado, dados de stock, isto é, da parte da população residente composta por migrantes internacionais. As melhores fontes para estes dados são os recenseamentos da população nos países de destino, considerando-se migrantes todos os residentes nascidos no estrangeiro. Estimativas intercensitárias são menos fiáveis por terem por base amostras sem dimensão para medir subpopulações migrantes por país de origem. Há por isso, neste artigo, um desfasamento entre a referência temporal dos dados sobre fluxos, em que é possível ter séries longas anuais até 2018, e os dados sobre stock, que em regra têm por base os recenseamentos da população nos países de destino em 2000/01 e 2010/11. 


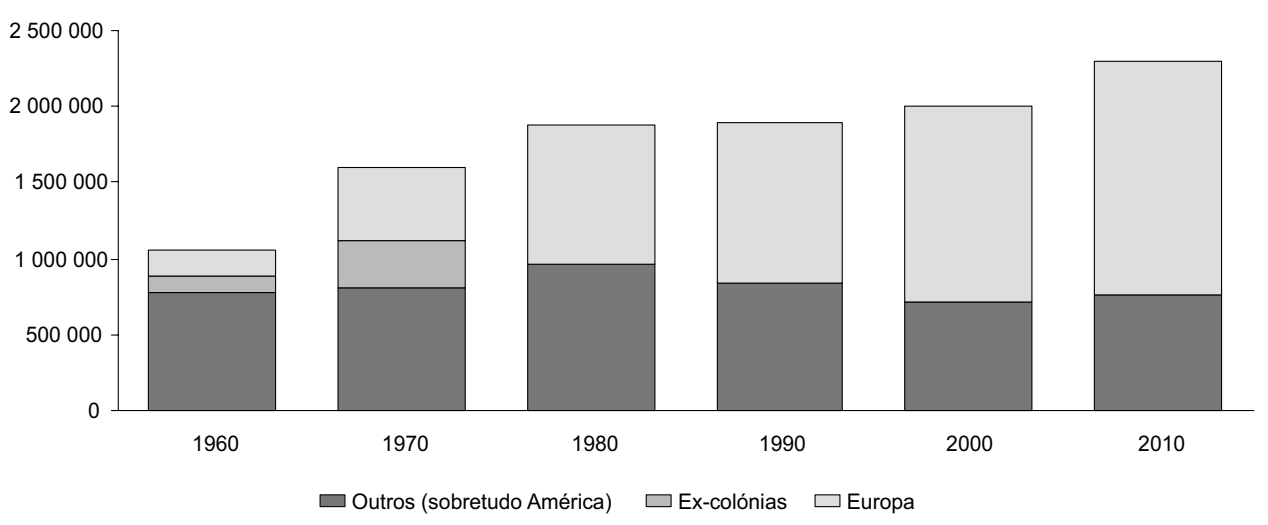

Figura 1 Evolução da população portuguesa emigrada, 1960-2010

Nota: nascidos em Portugal a residir no estrangeiro (stock).

Fontes: United Nations, Department of Economic and Social Affairs (2012), Trends in International Migrant Stock: Migrants by Destination and Origin (United Nations database, POP/DB/MIG/Stock/Rev.2012); The World Bank, Global Bilateral Migration Database; INE, Recenseamentos Gerais da População de Angola e Moçambique.

Quadro 1 Evolução da população portuguesa emigrada nos principais países de destino, 2000/01 e 2010/11

\begin{tabular}{|c|c|c|c|c|}
\hline \multirow{2}{*}{ País } & \multirow{2}{*}{$2000 / 01$} & \multirow{2}{*}{$2010 / 11$} & \multicolumn{2}{|c|}{ Variação } \\
\hline & & & Absoluta & Relativa (\%) \\
\hline Reino Unido & 36556 & 92065 & 55509 & 151,8 \\
\hline Espanha & 56359 & 98975 & 42616 & 75,6 \\
\hline Suíça & 100975 & 169459 & 68484 & 67,8 \\
\hline Luxemburgo & 41690 & 60897 & 19207 & 46,1 \\
\hline Alemanha & 70100 & 75110 & 5010 & 7,1 \\
\hline França & 581062 & 617234 & 36172 & 6,2 \\
\hline Canadá & 153530 & 140315 & -13215 & $-8,6$ \\
\hline EUA & 218646 & 191803 & -26843 & $-12,3$ \\
\hline Venezuela & 53477 & 37326 & -16151 & $-30,2$ \\
\hline Brasil & 213203 & 137973 & -75230 & $-35,3$ \\
\hline
\end{tabular}

Notas: (1) nascidos em Portugal a residir nos países de destino (stock); (2) dependendo do país, os recenseamentos foram realizados em 2000 e 2010 ou em 2001 e 2011; (3) o valor dos nascidos em Portugal residentes na Alemanha em 2001 foi estimado a partir dos dados da OCDE disponíveis na DIOC-2001, sendo baixa a fiabilidade do resultado obtido.

Fontes: Observatório da Emigração, valores dos recenseamentos nacionais da população dos países de residência consultados em Eurostat (Census Hub), Centro Latino-Americano e Caribenho de Demografia (Celade), US Census Bureau e Statistics of Canada.

Globalmente, a nova configuração dos destinos da emigração fez-se, pois, a par de um incremento desta no século XXI. A integração na Zona Euro é, nesta fase, a que podemos chamar a "quarta vaga da emigração portuguesa" (Pereira e Azevedo, 2019a), o acontecimento decisivo para a iniciação do novo ciclo de crescimento da emigração. De facto, a estagnação económica em Portugal que se seguiu à entrada no 


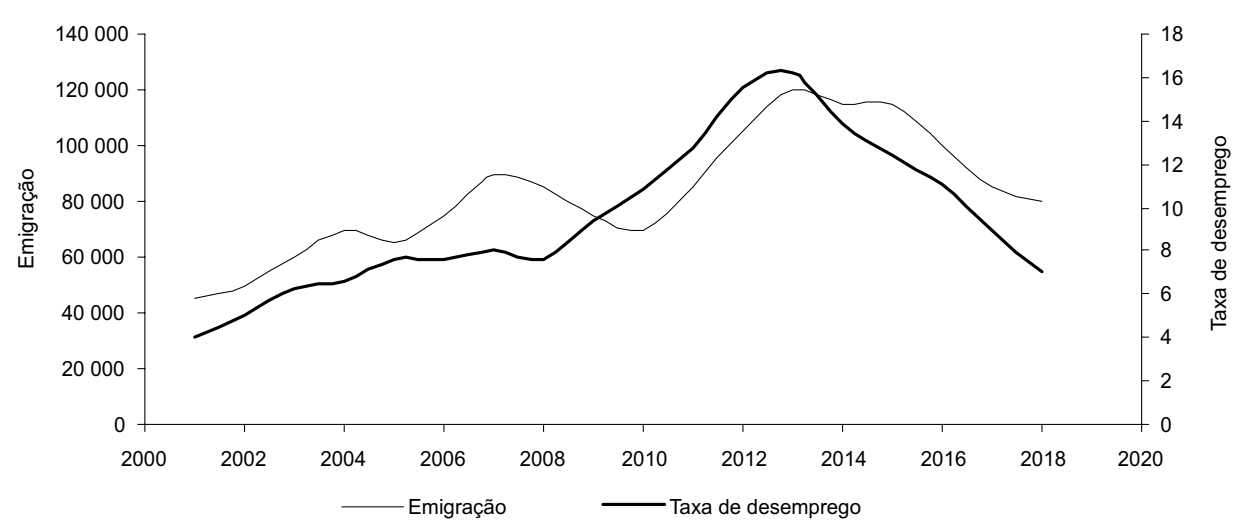

Figura 2 Emigração e desemprego, 2001-2018

Nota: entradas permanentes de portugueses nos países de destino (fluxo).

Fontes: estimativa do Observatório da Emigração com base nos dados sobre as entradas de portugueses nos países de destino (emigração); Instituto Nacional de Estatística, consultado via Pordata (taxa de desemprego)

Euro, bem como a consequente pressão depressiva sobre o investimento público (Lourtie, 2011) explicam o aumento da emigração, até 2008, pelos efeitos que teve no mercado de trabalho. A existência de uma correlação forte entre as dinâmicas do mercado de trabalho e as da emigração portuguesa é facilmente comprovável. Ao longo do século XXI, a evolução da emigração esteve negativamente correlacionada com a taxa de emprego e positivamente correlacionada com a taxa de desemprego (ver figura 2). As mesmas dinâmicas do mercado de trabalho que favoreceram a emigração dificultaram a imigração. A simetria foi quase perfeita, diminuindo a imigração à medida que a taxa de desemprego crescia e aumentando quando subia a taxa de emprego (Pires, 2019).

Importa explicar sumariamente a relação forte entre migrações e mercado de trabalho. Esta relação não se deve necessariamente a um predomínio das razões económicas nas decisões de migrar. A relação das migrações com as dinâmicas do mercado de trabalho é mais forte do que a relação das migrações com outras variáveis económicas porque a disponibilidade de emprego permite viabilizar todas as razões para migrar, sejam elas sociais, culturais ou mesmo políticas, não apenas as económicas. No final do processo de decisão, o potencial migrante tem sempre que assegurar as condições materiais de vida necessárias para concretizar as aspirações e projetos que associa à migração. Para a maioria das pessoas tal passa por ter um emprego. ${ }^{8}$

8 É por isso que deve haver prudência na atribuição de motivações económicas aos migrantes sempre que estes fazem parte de fluxos migratórios que têm, objetivamente, funções económicas. A facilidade em migrar porque no destino há procura de trabalho migrante diz pouco sobre as razões dos migrantes que tiram partido do contexto económico para concretizarem a sua mobilidade. Os estados subjetivos dos atores não podem ser deduzidos das consequências dos seus atos ou das características dos contextos que os viabilizam. 
A retoma de níveis elevados de emigração ao longo do século XXI teve apenas uma interrupção, entre 2008 e 2010, os anos da crise financeira e económica global. Nesses três anos a emigração diminuiu, apesar de se terem acentuado as dinâmicas recessivas no mercado de trabalho. Esta curta desassociação temporária entre dinâmicas migratórias e do mercado de trabalho espelha as diferenças entre a crise financeira de 2008/10 e a chamada crise das dívidas soberanas que lhe sucedeu e se prolongou, com mais intensidade, até 2013. A crise financeira, sendo global, reduziu o papel da migração internacional como alternativa à diminuição do emprego e ao crescimento do desemprego. Nessa conjuntura, a emigração portuguesa potencial teve menos destinos viáveis, como o tiveram então, em geral, praticamente todas as migrações internacionais (OECD, 2011: 30).

A partir de 2010, predominaram os efeitos da segunda fase da crise, agora assimétrica em vez de global. Crise e políticas de resposta à crise, de orientação austeritária, fizeram aumentar muito as saídas, uma vez mais pela combinação entre deterioração das condições de vida (a crise) e perceção de ausência de voz na resposta a esta deterioração (as políticas). Sendo agora a crise assimétrica, ou seja, abrangendo apenas países localizados sobretudo na periferia sul da Europa, havia destinos possíveis para a emigração, a norte, redes que a facilitavam e, inclusive, intervenções ativas de recrutamento a partir dos destinos possíveis. Assim, entre 2010 e 2013, ocorreu o crescimento mais elevado da emigração portuguesa desde os anos 60/70 do século XX. Em 2013, o novo ciclo emigratório atingiu o seu ponto culminante, com cerca de 120 mil saídas num único ano. É preciso recuar a 1973 para encontrar valores desta ordem de grandeza para a emigração.

A partir de 2014, iniciou-se um processo de retoma económica em Portugal, com crescimento do emprego e descida do desemprego. A taxa de emprego cresceu de $49,6 \%$, em 2013, para 55\%, em 2018, e a de desemprego desceu, no mesmo período, de $16,2 \%$ para $7 \%$. Os fluxos migratórios de e para Portugal acompanharam as novas tendências no mercado de trabalho, descendo a emigração e subindo a imigração. A diminuição da emigração tem sido, porém, mais lenta do que a recuperação da imigração. O número de saídas permanece, por isso, num patamar relativamente elevado, da ordem dos $0,9 \%$ da população residente em termos médios: mais de 100 mil por ano entre 2014 e 2016, e superior a 80 mil em 2017 e em 2018.

Uma análise mais atenta dos dados revela ainda que a descida da emigração portuguesa, depois do pico de 120 mil saídas em 2013, se fez a um ritmo mais lento do que aquele a que subiu nos anos anteriores, um pouco menos de $5 \%$ ao ano entre 2013 e 2018, cerca de um terço do valor a que cresceu entre 2010 e 2013. Este diferencial de ritmo deve-se aos efeitos de rede já referidos no início deste artigo. O crescimento do número de saídas na fase mais aguda da crise traduziu-se na ativação, revitalização e criação de redes entre origem e destino que tornam hoje mais fácil e provável a escolha da emigração como trajetória de mobilidade. Como refere Alejandro Portes, uma vez "estabelecidas, estas redes permitem que o processo de migração se torne autossustentado e impermeável a alterações de curto prazo nos incentivos económicos" (Portes, 1999: 27). As redes têm, porém, um tempo de vida após o qual vão enfraquecendo, entrando progressivamente num estado de latência. Por isso, o gráfico da evolução da emigração portuguesa desde 2010 assemelha-se 
cada vez mais à curva-tipo de formação, crescimento e declínio dos fluxos migratórios com efeito-diáspora, como conceptualizada por Hein de Haas (2010: 1606). Tendo em conta aqueles efeitos e a sua provável evolução, e persistindo diferenças de desenvolvimento económico significativas entre a periferia europeia, em que Portugal se integra, e os países centrais deste mesmo espaço, é provável que se mantenha a tendência lenta para a descida da emigração portuguesa, mas é improvável a imediata redução do seu volume para níveis anteriores à crise, apesar da retoma do crescimento da economia portuguesa, em particular da criação de emprego que caracterizou essa retoma até 2018. A tendência poderá, no entanto, ser alterada por efeito de fenómenos como o Brexit, que afeta o principal destino da emigração portuguesa, o Reino Unido, que chegou a ser responsável por quase um terço $(31 \%)$ das saídas de Portugal em 2016.

Para a maioria dos países de destino, a emigração acompanhou esta tendência geral, diminuindo o número de saídas para a Alemanha, França, Reino Unido e Suíça na segunda metade da década de 2010. Nos casos do Reino Unido e de Angola, a diminuição foi ainda mais acentuada, por sobreposição entre os efeitos de dinamização da economia portuguesa e os efeitos das crises naqueles dois países: crise de confiança no Reino Unido, devido ao Brexit (Vidigal e Pires, 2018), apesar da oscilação do fluxo em vésperas da saída (Vidigal, 2020), crise económica e financeira em Angola, devido à queda dos preços do petróleo. Em contrapartida, a emigração para Espanha evoluiu em contraciclo, aumentando mais de $17 \%$ ao ano, em termos médios, entre 2013 e 2018 (ver quadro 2 e figura 3).

Tendo em conta o paralelismo entre as dinâmicas da crise nos dois países ibéricos, percebe-se a especificidade da evolução da emigração de Portugal para Espanha. A Espanha, como Portugal, foi particularmente atingida tanto pela crise financeira global de 2008 como pela crise posterior das chamadas dívidas soberanas. O colapso do emprego, em 2008, em especial no setor da construção e obras públicas, foi ainda mais intenso em Espanha do que em Portugal, pondo em causa a viabilidade da emigração portuguesa para aquele país e induzindo, provavelmente, inúmeros retornos ou re-emigrações para outros países (Pires e Espírito-Santo, 2016: 9). Em consequência, não só diminuiu a emigração portuguesa para Espanha entre 2008 e 2013, como diminuiu o número de emigrantes a residir naquele país desde então. A partir de 2013, a economia e o emprego em Espanha retomaram uma trajetória de crescimento que, de novo, atraiu uma imigração portuguesa mais fácil de concretizar devido aos efeitos de vizinhança facilitadores de circulação e da sazonalidade dos fluxos. No entanto, apesar do crescimento das novas entradas ter tornado Espanha no segundo destino da emigração portuguesa, em 2018, não foi ainda suficiente para compensar as saídas por retorno ou re-emigração que se seguiram à crise de 2008. A emigração cresceu para Espanha a partir de 2014 mas o número de portugueses a residir naquele país manteve uma trajetória de diminuição entre 2009 e 2018, passando, nesse período, de quase 150 mil indivíduos para pouco menos de 95 mil.

Resumindo: na história sumária feita nesta secção, foram destacados vários acontecimentos que para ela contribuíram. Uns afetaram globalmente a evolução da emigração, como foi o caso da progressiva criação de um espaço europeu de 
Quadro 2 Evolução da emigração para os principais países de destino, 2001-2018

\begin{tabular}{|c|c|c|c|c|c|}
\hline \multirow{2}{*}{ País } & \multirow{2}{*}{$\begin{array}{c}2001 \\
\text { (ou primeiro ano } \\
\text { disponível) }\end{array}$} & \multirow{2}{*}{$\begin{array}{c}2018 \\
\text { (ou último ano } \\
\text { disponível) }\end{array}$} & \multirow{2}{*}{$\begin{array}{l}\text { Média anual } \\
2001-2018\end{array}$} & \multicolumn{2}{|c|}{ Valor mais elevado } \\
\hline & & & & Ano & Valor \\
\hline Total & 45000 & 80000 & 82778 & 2013 & 120000 \\
\hline Reino Unido & 4396 & 18871 & 17293 & 2015 & 32301 \\
\hline Suíça & 4347 & 8733 & 12924 & 2013 & 20039 \\
\hline França & 9165 & 8316 & 12273 & 2012 & 19658 \\
\hline Espanha & 3057 & 10636 & 9751 & 2007 & 27178 \\
\hline Alemanha & 9287 & 7200 & 7364 & 2015 & 14000 \\
\hline Luxemburgo & 2293 & 3501 & 3830 & 2012 & 5193 \\
\hline Brasil & 482 & 601 & 1103 & 2013 & 2904 \\
\hline EUA & 1609 & 939 & 1004 & 2001 & 1609 \\
\hline Canadá & 531 & 865 & 573 & 2018 & 865 \\
\hline Venezuela & .. & .. & .. & .. & .. \\
\hline
\end{tabular}

Notas: entradas permanentes de portugueses nos países de destino (fluxo); Brasil, só 2004-2017; Canadá, 2001-2017; França, 2003-2017; Venezuela, dados não disponíveis; Alemanha, valor máximo e ano de referência estimados.

Fontes: o valor total é uma estimativa do Observatório da Emigração a partir dos valores sobre as entradas de portugueses nos países de destino; os dados dos países foram recolhidos pelo Observatório da Emigração com base nos valores das entradas permanentes de portugueses registadas no Statistisches Bundesamt

Deutschland (Alemanha), ministérios do Trabalho e Emprego e da Justiça e Segurança Pública (Brasil),

Citizenship and Immigration Canada (Canadá), Instituto Nacional de Estadística (Espanha), US Department of Homeland Security (EUA), Institut National de la Statistique et de Etudes Economiques (França), Le Portail des Statistiques du Luxembourg (Luxemburgo), Department for Work and Pensions (Reino Unido) e Office Fédéral de la Statistique (Suíça).

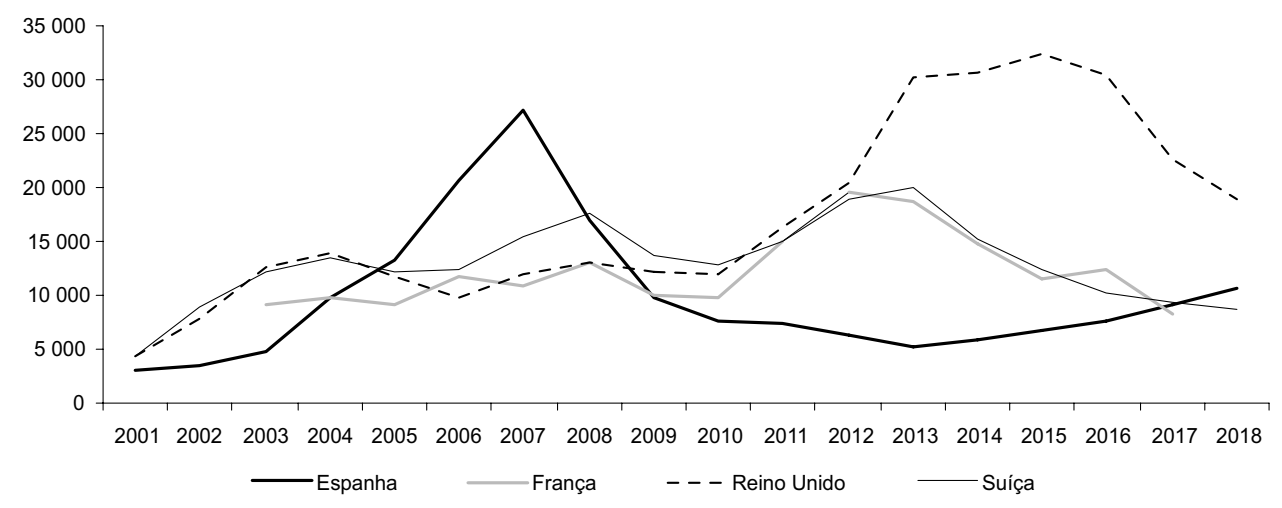

Figura 3 Evolução da emigração para os quatro principais países europeus de destino, 2001-2018 Nota: entradas permanentes de portugueses nos países de destino (fluxo).

Fontes: Observatório da Emigração com base nos valores das entradas permanentes de portugueses registadas no Instituto Nacional de Estadística (Espanha), Institut National de la Statistique et de Etudes Economiques (França), Department for Work and Pensions (Reino Unido) e Office Fédéral de la Statistique (Suíça). 
livre circulação e, posteriormente, da integração de Portugal na Zona Euro, bem como as dinâmicas mutáveis da crise económica e financeira iniciada em 2008. Outros afetaram, sobretudo, fluxos particulares de emigração, como a intensidade maior da componente imobiliária na crise de 2008 em Espanha ou, mais recentemente, a saída do Reino Unido da União Europeia.

\section{Padrões}

Como se viu, ao longo das duas primeiras décadas do século XXI, os fluxos totais de emigração a partir de Portugal voltaram a ter um volume considerável, apesar da desaceleração ocorrida a partir de 2013. Aumentou, também, a população portuguesa emigrada, em termos de stock. De acordo com estimativas das Nações Unidas, em 2015, o número de emigrantes nascidos em Portugal a viver no estrangeiro seria da ordem dos 2,3 milhões, o valor mais elevado desde que aquele organismo internacional publica estimativas sobre as migrações internacionais por país. ${ }^{9}$

A retoma da emigração foi, no entanto, desigual. Como referido na secção anterior, acentuou-se, no pós-1974, a regionalização da emigração portuguesa, agora mais concentrada em destinos europeus, parte dos quais novos destinos com pouca relevância no período anterior. Este processo de europeização dos fluxos teve resultados acumulados que se manifestaram na constituição de populações emigradas com características diferenciadas. Os dados disponíveis permitem distinguir três conjuntos de destinos, em função dos diferentes perfis demográficos das populações portuguesas aí emigradas:

- países com populações portuguesas emigradas numerosas mas envelhecidas e em declínio devido à redução continuada dos fluxos com origem em Portugal desde os anos 60, que não voltaram a crescer, sendo hoje insuficientes para compensar a mortalidade e movimentos de retorno e de re-emigração (em particular no continente americano, casos do Brasil, Venezuela, EUA e Canadá);

- países com populações portuguesas emigradas numerosas e envelhecidas mas em crescimento, para os quais ocorreu uma retoma mais intensa da emigração no século XXI que foi suficiente para inverter as tendências recessivas anteriores, mas não para compensar o seu envelhecimento (França, Alemanha e Luxemburgo);

- países com populações portuguesas emigradas jovens e em crescimento, que se tornaram novos destinos importantes da emigração portuguesa no pós-1974, mas com trajetórias, desde então, muito diversas (Suíça, Espanha e Reino Unido).

9 United Nations, DESA, Population Division: International Migrant Stock (the 2015 revision) (www.un.org/en/development/desa/population/migration/data/estimates2/estimates15.shtml). 
Ou seja, os antigos destinos intercontinentais da emigração portuguesa estão em declínio acentuado enquanto os situados na Europa estão em revitalização ainda que em escala menos vasta do que no passado. O crescimento da emigração neste século resultou, portanto, da emergência de novos destinos no espaço europeu. E a emergência de novos destinos significou, também, a emergência de novos tipos de emigração, como se conclui analisando as características sociodemográficas da população emigrada.

Essa análise requer informação só disponível nos recenseamentos da população, em regra realizados a cada dez anos. Os últimos censos disponíveis para os principais destinos da emigração portuguesa são os de 2010/11 (o que não permite captar os resultados do período pós-2010, exatamente o de maior crescimento da nova emigração). A análise que se segue foca-se, por isso, na caracterização sociodemográfica da população emigrada nascida em Portugal a viver no estrangeiro em 2000/01 e em 2010/11, bem como nas mudanças ocorridas entre estes dois anos. Tem, também, um foco regional nos países da OCDE, espaço para o qual existe informação razoavelmente harmonizada sobre populações emigradas que falta para outros destinos da emigração portuguesa. ${ }^{10}$

Em termos agregados, é possível caracterizar a população portuguesa emigrada nos países da OCDE, na primeira década do século XXI, como uma população equilibrada na distribuição por sexo, com $51 \%$ de homens em ambos os períodos censitários (2000/01 e 2010/11), e composta maioritariamente por indivíduos em idade ativa. Analisando a estrutura etária, observa-se uma tendência clara para o envelhecimento, o que significa que o crescimento da emigração portuguesa na primeira década do novo século foi, como já atrás referido, insuficiente para compensar, neste plano, a redução nas saídas de Portugal ocorrida entre 1974 e finais do século XX. A tendência é claramente ilustrada pelo crescimento do grupo etário dos mais de 64 anos, que passou de $9 \%$ para $17 \%$ da população emigrada total entre 2001 e 2011.

O predomínio, em termos agregados, do legado da emigração do século XX, que está na origem da tendência para aquele envelhecimento, fica expresso noutro

10 Os dados usados nesta parte do artigo foram extraídos das bases DIOC organizadas pela OCDE e disponíveis em regime de livre acesso no sítio desta organização internacional (www.oecd.org/els/mig/dioc.htm). Destas bases, que compilam e harmonizam microdados censitários sobre migrações internacionais no espaço da OCDE, foram extraídas sub-bases sobre a emigração portuguesa já preparadas para serem trabalhadas em SPSS, disponibilizadas em regime de acesso livre no sítio do Observatório da Emigração. Para uma especificação dos problemas de fiabilidade destas bases e uma descrição mais pormenorizada dos indicadores e dados, ver Observatório da Emigração (2015) e Pires et al. (2014). Sobre as limitações da focagem no espaço da OCDE, deve ser assinalado que, em 2010/11, residiam nos países deste espaço um milhão e meio de indivíduos nascidos em Portugal, o que representava mais de $75 \%$ dos dois milhões de portugueses emigrados em todo o mundo, de acordo com as estimativas das Nações Unidas. Ou seja, as fontes usadas cobrem boa parte da emigração portuguesa, ficando apenas de fora, entre os destinos mais relevantes, o Brasil, a Venezuela, Angola e Moçambique. Sobre os dois últimos não há dados censitários disponíveis sobre as populações de naturais de Portugal aí residentes. Sobre Brasil e Venezuela é possível obter dados agregados não harmonizados com os existentes para o conjunto dos países da OCDE. Estão disponíveis, em regime de acesso livre, na base de dados com os censos dos países da América Latina e Caraíbas organizada pela Comissão Económica para a América Latina das Nações Unidas (CEPAL), em http://celade.cepal.org/bdcelade/imila/ (acessível, também, através do sítio do Observatório da Emigração). 
indicador: $85 \%$ dos emigrantes portugueses a viver em países da OCDE, em 2000/01, tinha emigrado há mais de dez anos, percentagem que desceu para $81 \%$ em 2010/11, refletindo já a retoma de fluxos de emigração de maior porte na primeira década do novo século. A fixação prolongada dos emigrantes portugueses explica, também, as elevadas taxas de aquisição da nacionalidade dos países de destino, que passou de $35 \%$ para $40 \%$ entre $2000 / 01$ e 2010/11. ${ }^{11}$ E explica, igualmente, o crescimento dos inativos, que passaram de $29 \%$ para $32 \%$, entre 2001 e 2011 , devido ao envelhecimento acima referido e o consequente crescimento do número de reformados.

Ainda em termos agregados, assinale-se o predomínio, na população emigrada, de indivíduos com baixas e muito baixas qualificações, apesar do crescimento significativo da percentagem dos mais qualificados, em linha com a crescente escolarização da população portuguesa na origem. A percentagem dos emigrados com formação superior praticamente duplicou, passando de $6 \%$ para $11 \%$ entre 2001 e 2011. Voltaremos à questão da qualificação na emigração portuguesa, que tem sido objeto de debate alargado tanto na comunidade científica como no plano mediático e político.

Quando se completa a análise em termos agregados com um estudo das variações e diferenças entre as populações emigradas nos vários países de destino, fica mais clara a existência de múltiplos padrões migratórios, tanto no plano demográfico como no plano social. Para a identificação desses padrões foram importantes os resultados da análise de três indicadores: idade, tempo de estadia no país de destino e qualificação dos portugueses emigrados (ver quadro 3).

Comecemos com a análise da distribuição por grupo etário da população portuguesa emigrada nos diferentes países de fixação. Os destinos antigos da emigração intercontinental são, como já se referiu, aqueles que têm populações emigradas mais envelhecidas, com o grupo dos mais de 64 anos a representar, em todos eles, mais de $20 \%$ da população residente nascida em Portugal: no Canadá essa percentagem atingiu um máximo de $28 \%$ em 2010/11. Foi também entre os portugueses emigrados neste grupo de países que mais cresceu o peso dos idosos (mais de 64 anos): no Canadá, aumentou 11 pontos percentuais, passando de $17 \%$ para $28 \%$, entre 2001 e 2011, e nos EUA aumentou sete pontos percentuais, de $16 \%$ para $23 \%$. Crescimento elevado da percentagem dos idosos é ainda observável entre os emigrantes portugueses em

11 Esta percentagem elevada deve-se, sobretudo, aos efeitos dos regimes de nacionalidade baseados no direito de solo que vigora em países como os EUA e o Canadá. Diferentes regimes de nacionalidade têm efeitos na medição do stock de emigrantes em função do indicador usado. O indicador mais consensualizado é, como já se referiu, o da naturalidade: são migrantes num país os que aí residem mas nasceram noutro país. Quando este indicador não está disponível, é usado como proxy a nacionalidade: são migrantes num país os que aí residem mas têm nacionalidade estrangeira. O uso desta proxy encerra, porém, a possibilidade de erros de medida elevados. Um exemplo simples, comparando dados sobre a emigração para a Alemanha e o Canadá. A população com nacionalidade portuguesa residente na Alemanha representava, em 2013, mais de $120 \%$ da população portuguesa emigrada nascida em Portugal a residir naquele país europeu. Pelo contrário, no Canadá, em 2006, o número de pessoas com nacionalidade portuguesa equivalia a apenas $21 \%$ da população emigrada no país nascida em Portugal. 
Quadro 3 População portuguesa emigrada nos países da OCDE, indicadores sociodemográficos, 2000/01 e 2010/11

\begin{tabular}{|c|c|c|c|c|c|c|c|c|}
\hline \multirow{2}{*}{ País } & \multicolumn{2}{|c|}{$\begin{array}{c}\text { Residentes nascidos } \\
\text { em Portugal }\end{array}$} & \multicolumn{2}{|c|}{$\begin{array}{c}\text { Com } 65 \text { ou mais anos } \\
(\%)\end{array}$} & \multicolumn{2}{|c|}{$\begin{array}{l}\text { A residir no destino há } \\
10 \text { ou mais anos }(\%)\end{array}$} & \multicolumn{2}{|c|}{$\begin{array}{c}\text { Com diploma } \\
\text { do ensino superior (\%) }\end{array}$} \\
\hline & $2000 / 01$ & $2010 / 11$ & $2000 / 01$ & $2010 / 11$ & $2000 / 01$ & $2010 / 11$ & $2000 / 01$ & $2010 / 11$ \\
\hline Total & 1258552 & 1435776 & 10,8 & 16,8 & 84,0 & 81,0 & 6,8 & 11,2 \\
\hline Alemanha & 67720 & 64379 & (c) & (c) & (c) & (c) & (c) & (c) \\
\hline Austrália & 14959 & 15104 & 10,7 & 23,0 & 93,2 & 93,5 & 8,0 & 15,7 \\
\hline Áustria & 873 & & 3,8 & & & & 11,7 & \\
\hline Bélgica & 19870 & 26358 & 6,7 & 8,5 & 56,4 & 58,7 & 10,6 & 10,5 \\
\hline Canadá & 153985 & 139275 & 17,0 & 27,6 & 93,5 & 96,7 & 10,0 & 16,5 \\
\hline Chile (a) & & 13 & .. & n.s. & & n.s & & n.s. \\
\hline Dinamarca & 634 & 1138 & 6,0 & 8,3 & 61,4 & 30,9 & 30,8 & 33,6 \\
\hline Eslováquia & 4 & 22 & n.s. & n.s. & n.s. & n.s & n.s & n.s. \\
\hline Eslovénia (a) & & 20 & & n.s. & & n.s & & n.s \\
\hline Espanha & 53420 & 91620 & 12,8 & 11,7 & 77,5 & 60,3 & 7,5 & 13,0 \\
\hline Estónia (a) & & 23 & & n.s. & & n.s & & n.s \\
\hline EUA & 206340 & 198846 & 16,0 & 22,8 & 90,3 & 94,5 & 11,0 & 14,2 \\
\hline Finlândia & 155 & 327 & 0,0 & 3,1 & & 30,3 & 19,4 & 22,6 \\
\hline França & 567700 & 588223 & 8,2 & 16,1 & 88,3 & 89,1 & 4,1 & 6,5 \\
\hline Grécia & 279 & 313 & 3,9 & 10,2 & 45,2 & 64,3 & 19,4 & 29,4 \\
\hline Hungria & 24 & 242 & 8,3 & 10,0 & & 15,5 & n.s. & 34,7 \\
\hline Irlanda & 537 & 1939 & 1,1 & 1,7 & 13,9 & 18,2 & 34,8 & 36,8 \\
\hline Islândia (a) & & 367 & .. & 1,1 & & 0,0 & & 14,2 \\
\hline Itália & 3868 & 4835 & 6,4 & 12,0 & 49,0 & 71,7 & 13,7 & 17,4 \\
\hline Japão & & 359 & .. & 9,2 & .. & & .. & 49,2 \\
\hline Luxemburgo & 38398 & 56450 & 2,5 & 5,4 & 43,1 & 70,0 & 2,1 & 4,1 \\
\hline México & 263 & 320 & 12,5 & 10,9 & & & 50,4 & 44,7 \\
\hline Noruega & 583 & 1126 & 6,3 & 4,4 & 65,3 & 38,7 & 14,5 & 39,8 \\
\hline Nova Zelândia & 141 & & 10,6 & .. & 47,9 & & 28,9 & \\
\hline Países Baixos & (b) & 9398 & (b) & 5,4 & (b) & 68,1 & (b) & 11,6 \\
\hline Polónia & 33 & 92 & n.s. & n.s. & .. & n.s & n.s & 73,9 \\
\hline Reino Unido & 32263 & 79199 & 6,4 & 6,5 & 52,9 & 41,0 & 19,3 & 38,3 \\
\hline República & 28 & 361 & n.s. & 0,0 & .. & .. & n.s & 36,4 \\
\hline Checa & & & & & & & & \\
\hline Suécia & 2275 & 2850 & 10,1 & 18,9 & 82,2 & 69,3 & 16,9 & 28,2 \\
\hline Suiça & 94200 & 152577 & (c) & (c) & 68,9 & 66,9 & 2,7 & 6,1 \\
\hline Turquia & .. & .. & .. & .. & .. & .. & .. & .. \\
\hline
\end{tabular}

Notas: nascidos em Portugal a residir nos países da OCDE (stock 15 e mais anos); [...] dados não disponíveis; [n.s.] valores não significativos; (a) países não incluídos na base de dados em 2000/01; (b) dados com problemas de fiabilidade em 2000/01; (c) dados com problemas de fiabilidade em 2000/01 e em 2010/11. Fonte: cálculos do Observatório da Emigração, valores da OCDE, Database on Immigrants in OECD Countries, DIOC 2000/01, ficheiro A2, e DIOC 2010/11, Rev 3, ficheiros B (tempo de estadia) e C (restantes variáveis).

França, destino europeu mais antigo. Essa percentagem duplicou, passando de $8 \%$ para $16 \%$ entre 2002 e 2011, tendo, porém, valores de partida e de chegada bastante mais baixos do que os referidos para os destinos transcontinentais.

Contrastando com o envelhecimento ocorrido nos antigos países de emigração, nas populações portuguesas emigradas nos novos países de destino, e em particular nos que se afirmaram como tal na primeira década do século XXI, o grupo etário dos mais de 64 anos não só tinha menor expressão como decresceu ou não se alterou entre 2000/01 e 2010/11. A percentagem de idosos diminuiu ligeiramente entre os portugueses emigrados em Espanha, passando de $13 \%$ para $12 \%$, e manteve-se praticamente inalterada entre os que viviam no Reino Unido, em torno dos 
$6,5 \%$. Os dados sobre a condição perante o trabalho são congruentes com os dados sobre a estrutura etária. Nos principais países da emigração mais antiga, Canadá e EUA, era elevada a percentagem de inativos, sobretudo reformados, da ordem dos $40 \%$ em 2010/11. Pelo contrário, no principal destino da emigração atual, o Reino Unido, esse valor não ultrapassava os $25 \%$, no mesmo ano.

A distinção entre antigos e novos países de destino da emigração pode ser clarificada analisando os dados sobre a duração da estadia dos emigrantes portugueses radicados nos países da OCDE. No Canadá e EUA, mais de 90\% dos emigrantes que aí viviam em 2001 estavam radicados há mais de dez anos. Essa percentagem subiu em 2011, atingindo um valor máximo de $94 \%$ no Canadá. Ou seja, a população portuguesa nestes países é não só antiga como deixou de ser alimentada por novos fluxos com dimensão significativa. Em situação parecida encontrava-se a população emigrada em França: 89\% vivia neste país há mais de dez anos, tanto em 2001 como em 2011. Neste caso, porém, é visível a retoma da emigração, embora ainda a níveis muito inferiores à dos anos 60 do século XX, como é indicado pelo facto de ter crescido de $4 \%$ para $7 \%$ a percentagem de emigrantes radicados no país há menos de cinco anos.

Dinâmicas opostas são evidentes na emigração portuguesa para o Reino Unido e para novos destinos da emigração ainda de reduzida dimensão, como a Irlanda, a Dinamarca e a Noruega. Em todos estes casos, a população portuguesa emigrada há mais de dez anos era inferior a 50\% do total em 2011, com um mínimo de $18 \%$ na Irlanda. No Reino Unido, que se tornou nas duas últimas décadas o principal destino da nova emigração portuguesa, o conjunto dos emigrantes portugueses aí radicados há mais de dez anos desceu de $53 \%$, em 2001, para $41 \%$, em 2011, ao mesmo tempo em que subiu a percentagem dos radicados há menos de cinco anos, de $21 \%$ para $35 \%$. Em posição intermédia, encontrava-se a população portuguesa emigrada em Espanha, confirmando os dados um arranque mais precoce da nova emigração para este país, logo nos primeiros anos do século XXI. A percentagem de portugueses aí radicados há menos de cinco anos passou de $14 \%$ para $24 \%$, entre 2000/01 e 2010/11. Porém, a percentagem dos que tinham emigrado entre cinco a dez anos antes do censo duplicou, passando de $8 \%$ para $16 \%$, no mesmo período.

Como atrás se referiu, a população portuguesa emigrada era, em 2011, mais qualificada do que em 2001. Em termos absolutos, essa maior qualificação deveu-se, no essencial, à nova emigração para o Reino Unido. Neste país, o número de emigrados portugueses com o ensino superior duplicou nos dez anos em análise, passando de $19 \%$, um valor já comparativamente elevado, para $38 \%$. Como, no mesmo período, o número total de emigrantes portugueses com mais de 15 anos a residir no Reino Unido foi também dos que mais cresceu, passando de 29 mil para 79 mil, aquele aumento percentual traduziu-se num aumento em números absolutos ainda mais expressivo. Tal não significa, porém, uma maior concentração da emigração qualificada. Por razões adiante explicadas, a emigração qualificada foi, este século, mais dispersa, em termos de destinos, do que a emigração menos qualificada.

Em 2011, a percentagem de emigrantes portugueses com ensino superior ultrapassava os 30\% em mais três países para além do Reino Unido: Irlanda, Dinamarca e Noruega, países com populações portuguesas emigradas de reduzida dimensão, embora em crescimento. $\mathrm{Na}$ maioria dos destinos da emigração portuguesa no 
espaço da OCDE, a percentagem de emigrantes residentes com ensino superior não registou aumentos significativos entre 2000/01 e 2010/11. As exceções foram o Reino Unido, a Noruega e a Suécia.

No outro extremo da escala das qualificações, a evolução da percentagem de emigrantes com mais de 15 anos e apenas o ensino básico é simétrica da analisada nos parágrafos anteriores. Com uma exceção: no Luxemburgo, a percentagem de emigrantes nascidos em Portugal que não foram além do ensino básico aumentou oito pontos percentuais entre 2001 e 2011 , passando de $65 \%$ para $73 \%$. Esta evolução em contracorrente confirma o Luxemburgo como um dos destinos da emigração de trabalho menos qualificado da história portuguesa recente. Olhando apenas para o ponto de chegada, em 2011, apenas num outro país a percentagem de emigrantes nascidos em Portugal com, no máximo, o ensino básico era maior: Espanha, com $74 \%$. No entanto, neste país a percentagem de emigrantes portugueses com formação superior era três vezes maior do que no Luxemburgo ( $13 \%$ contra $4 \%$ ), o que indicia a existência de uma sobreposição de fluxos migratórios para Espanha, antes de 2008, com um fluxo maioritário de migrações de trabalho ainda menos qualificado do que o que se dirigia para o Luxemburgo, a par de uma migração minoritária mais qualificada.

Vale a pena analisar mais em pormenor a questão da qualificação na emigração portuguesa deste século (Cândido, 2018; Justino, 2016; Pires e Pereira, 2018). Existe hoje disseminada a ideia de que Portugal passou a ser um país de emigração de quadros, o que está longe de corresponder à realidade. A emigração atual, pós-crise de 2008 , continua a ser maioritariamente composta por trabalhadores pouco qualificados. Retomando indicadores e valores já referidos: na primeira década do século XXI, a percentagem de diplomados do ensino superior na população portuguesa emigrada nos países da OCDE passou de 6\%, em 2001, para 11\%, em 2011. No mesmo período cresceu ainda mais a taxa de qualificação da população residente em Portugal com idade superior a 15 anos: a percentagem de diplomados passou de $8 \%$, em 2001, para $14 \%$, em 2011. Isto significa que o aumento da qualificação da população portuguesa emigrada foi, até 2010, o resultado do aumento da qualificação da população portuguesa em geral, mais do que de uma maior incidência da emigração nos setores qualificados. Os dados mostram, também, que a população portuguesa emigrada continuava a ser maioritariamente composta por indivíduos com qualificações médias e baixas: em 2010/11, 62\% dos emigrantes portugueses a residir em países da OCDE, com 15 e mais anos, tinham, no máximo, o ensino básico e $27 \%$ o secundário. Ou seja, quase nove em cada dez tinham um nível de instrução inferior ao da licenciatura.

Esta estrutura de qualificações do conjunto da população emigrada era, em parte, o resultado acumulado da história. Quando se analisa a composição da população portuguesa emigrada por país de destino observa-se uma clara relação entre a estrutura das qualificações e a longevidade da emigração. Tendencialmente, quanto maior é a percentagem da população com uma fixação mais prolongada, menor é a taxa de qualificação. Em 2010/11, a percentagem de imigrantes portugueses com 15 e mais anos a viver em países da OCDE e que tinham um diploma de ensino superior variava entre os $9 \%$, no caso dos emigrados há mais de 20 anos, e os $33 \%$, no caso dos emigrados há um ano ou menos (ver figura 4 ). 


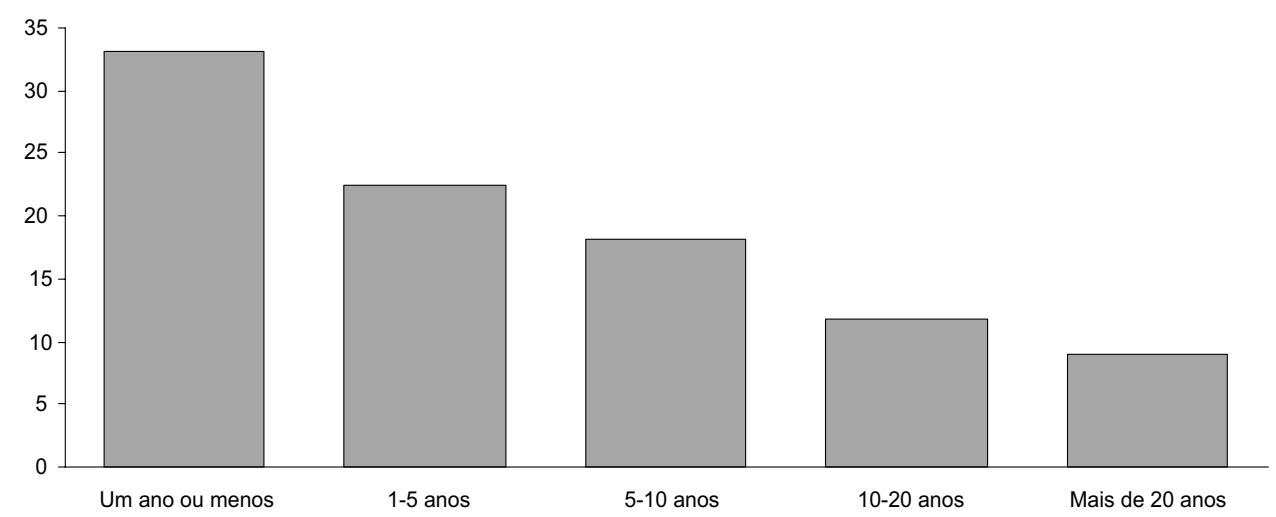

Figura 4 Percentagem de diplomados do ensino superior na população portuguesa emigrada nos países da OCDE, segundo o tempo de residência no país de destino, 2010/11

Notas: nascidos em Portugal a residir nos países da OCDE (stock 15 e mais anos); diplomas do ensino superior correspondem aos níveis ISCED 5A/5B/6.

Fonte: cálculos do Observatório da Emigração, dados da OCDE, Database on Immigrants in OECD Countries, DIOC 2010/11, Rev 3, ficheiro C.

Analisando apenas os dados sobre as qualificações dos emigrantes portugueses que viviam há um ano no país de destino, assim se anulando o efeito da história, é possível discernir um novo padrão migratório, agora já não no plano demográfico mas no plano social (Pires e Pereira, 2018):12

- os licenciados eram maioritários nos fluxos que, em 2010/11, se dirigiam para os novos países de emigração: Irlanda (64\%), Noruega (55\%) e Reino Unido (55\%);

- em regra, os licenciados estavam em minoria nos fluxos que, em 2010/11, se dirigiam para os antigos países de emigração, variando a percentagem dos que tinham no máximo o ensino básico entre os 39\%, na emigração para Itália, e os $73 \%$, na emigração para França.

Este padrão de diferenciação entre níveis de qualificação na emigração para antigos e novos países de destino resulta do grau socialmente variável da centralidade das redes na constituição dos fluxos migratórios. Como já se referiu, as redes são decisivas na reprodução de fluxos mais do que na sua constituição. As redes sociais estão frequentemente em estado de latência, podendo ser ativadas por vários modos. As redes latentes na emigração portuguesa em finais do século XX eram, em regra, redes constituídas nas décadas anteriores no âmbito de fluxos maioritariamente percorridos por emigrantes com baixas qualificações escolares e inseridos em empregos pouco

12 Quando se isola, nos censos de 2010/11, os emigrados a viver no país há menos de um ano, ficamos com a população correspondente ao fluxo de entradas no último ano. Na prática, é como se os dados assim obtidos fossem dados sobre o fluxo, no ano anterior ao da aplicação do censo, e não dados sobre stock. 
qualificados, tanto na origem como no destino. A ativação dessas redes na retoma da emigração foi, por isso, socialmente seletiva, facilitando sobretudo a retoma de fluxos semelhantes aos que tinham estado na sua origem. Nos países de destino da velha emigração, a ativação de redes latentes serviu, como os dados sugerem, para viabilizar uma nova vaga de emigração pouco qualificada para países como a França, a Alemanha ou o Luxemburgo. Apenas um exemplo. Excecionalmente, estão disponíveis dados sobre a entrada de emigrantes em França, em 2012, por nacionalidade e escolarização. De acordo com esses dados, do Institut National de la Statistique et des Etudes Economiques (INSEE), entraram em França, naquele ano, cerca de 18 mil portugueses. Destes, só $14 \%$ tinham um diploma do ensino superior, o que fazia da migração de portugueses a menos qualificada, a par com a dos turcos, entre as 20 mais numerosas que, naquele ano, tiveram a França por destino. A título de comparação, tinham um diploma do ensino superior $56 \%$ dos espanhóis, 33\% dos argelinos e $23 \%$ dos marroquinos nesse ano entrados em França (Espírito-Santo e Pereira, 2015).

O crescimento da emigração para novos destinos contou menos com o suporte das redes interpessoais. Outros mecanismos, desde a oferta promovida por agências formais de recrutamento, de que o melhor exemplo será o da procura de enfermeiros para trabalhar no Reino Unido (Pereira, 2015; Pereira, Pinto e Pires, 2015), ${ }^{13}$ até à procura ativa por potenciais emigrantes de oportunidades de trabalho publicamente divulgadas em domínios mais internacionalizados, terão desempenhado um papel inicial mais importante na iniciação de fluxos para novos destinos. Este tipo de mecanismos tende a selecionar migrantes mais qualificados, quer porque a procura de trabalho migrante qualificado é ativamente promovida e apoiada pelos estados dos países de destino, quer porque são maiores as competências requeridas para encontrar e responder a oportunidades que circulam em termos impessoais e organizacionais. Uma vez mais, os dados atrás analisados são congruentes com a menor dependência de redes interpessoais nos fluxos migratórios mais qualificados, como já observado em muitos outros contextos migratórios (Goldin, Cameron e Blarajan, 2011: 107). Claro que, uma vez estabelecidos estes fluxos, constituem-se novas redes que se somam aos mecanismos mais impessoais acima referidos, o que significa que o potencial migratório nos setores mais qualificados da população dispõe de mais recursos para se concretizar. Novas redes que operam também seletivamente, do ponto de vista social, sustentando sobretudo a reprodução de fluxos de emigração qualificada, numa lógica de sobreposição forte, ainda que incompleta, entre classe e rede, já assinalada em termos mais gerais por autores como Peter Blau (1977).

Globalmente, ao crescimento da nova emigração qualificada, induzido pelo surgimento de novos destinos, correspondeu uma maior desigualdade nos valores

13 Comoé assinalado em Pereira (2015), o início do recrutamento alargado de enfermeiros portugueses seguiu-se à decisão do então primeiro-ministro britânico, David Cameron, de reduzir drasticamente a imigração com origem em países exteriores à União Europeia, interrompendo assim os grandes fluxos de enfermeiros indianos e filipinos para o Reino Unido. É um bom exemplo dos impactos indiretos das políticas migratórias na evolução dos fluxos, neste caso o contributo do fechamento à imigração extraeuropeia para a constituição de novos fluxos intraeuropeus (de enfermeiros portugueses e espanhóis para o Reino Unido). 
das taxas de emigração por qualificação. A análise dos dados disponíveis permite concluir que, no ano de 2010/11, emigraram para países da OCDE 0,17\% das pessoas nascidas em Portugal que tinham concluído, no máximo, o ensino básico, aumentando esta taxa para $0,33 \%$ no caso dos que tinham concluído o secundário e para $0,68 \%$ dos que detinham um diploma do ensino superior (Pires e Pereira, 2018: 347-348). ${ }^{14}$ De acordo com estes dados, a probabilidade de emigração entre os portugueses era, pois, tanto maior quanto mais elevado fosse o seu nível de instrução.

Em conclusão, embora na nova emigração portuguesa continuem a ser maioritários os fluxos de baixa qualificação, houve transformações significativas na relação entre emigração e qualificações, pois: ${ }^{15}$

- é hoje maior do que no passado a percentagem de detentores de um grau do ensino superior entre os que emigram;

- essa maior percentagem de emigrantes qualificados está a crescer mais do que a percentagem dos não qualificados;

- a probabilidade de emigração é hoje maior entre os portugueses com mais qualificações do que entre os menos qualificados.

\section{O contexto europeu}

Com 2,3 milhões de emigrantes, de acordo com estimativas das Nações Unidas para 2015, Portugal não é um grande país de emigração em termos absolutos, como o México ou a Índia, com mais de 11 milhões de emigrados cada. Em 2015, Portugal era "apenas" o 27.․ país do mundo com mais emigrados. Porém, se ponderarmos o número de emigrados pela população do país de origem, Portugal sobe várias posições na hierarquia. Com uma taxa bruta de emigração de $22,3 \%$, em termos de stock, ${ }^{16}$ Portugal era, neste indicador, o 12.ำ país do mundo com mais pessoas emigradas.

Focando a comparação apenas no quadro da União Europeia, conclui-se que Portugal ocupava, em 2015, o segundo lugar entre os países com mais emigrados em percentagem da população (23\%), e o primeiro considerando apenas os países com mais de um milhão de habitantes (em primeiro lugar, sem esta ressalva, estava Malta). Em contraste, era um dos países com menor percentagem de imigrantes na população residente, abaixo da média dos países da União Europeia: $8 \%$ se considerarmos os repatriados da descolonização nascidos nas ex-colónias, menos de 7\% sem estes. A conjugação de alta emigração com baixa imigração, em termos de stock, situava Portugal

14 O universo em causa inclui, apenas, pessoas com 15 e mais anos.

15 Para uma análise mais pormenorizada dessas transformações e, em particular, do crescimento da emigração qualificada e das suas características e modalidades particulares, ver Lopes (2014), Gomes (coord.) (2015b) e Peixoto et al. (2016).

16 Taxa bruta de emigração: stock de emigrantes permanentes num ano em percentagem ou permilagem da população de residência do país de origem nesse mesmo ano. Taxa bruta de imigração: stock de imigrantes permanentes num ano em percentagem ou permilagem da população de residência do país de destino nesse mesmo ano. Nos dois casos, o ano de referência é, habitualmente, o de aplicação de um censo. 


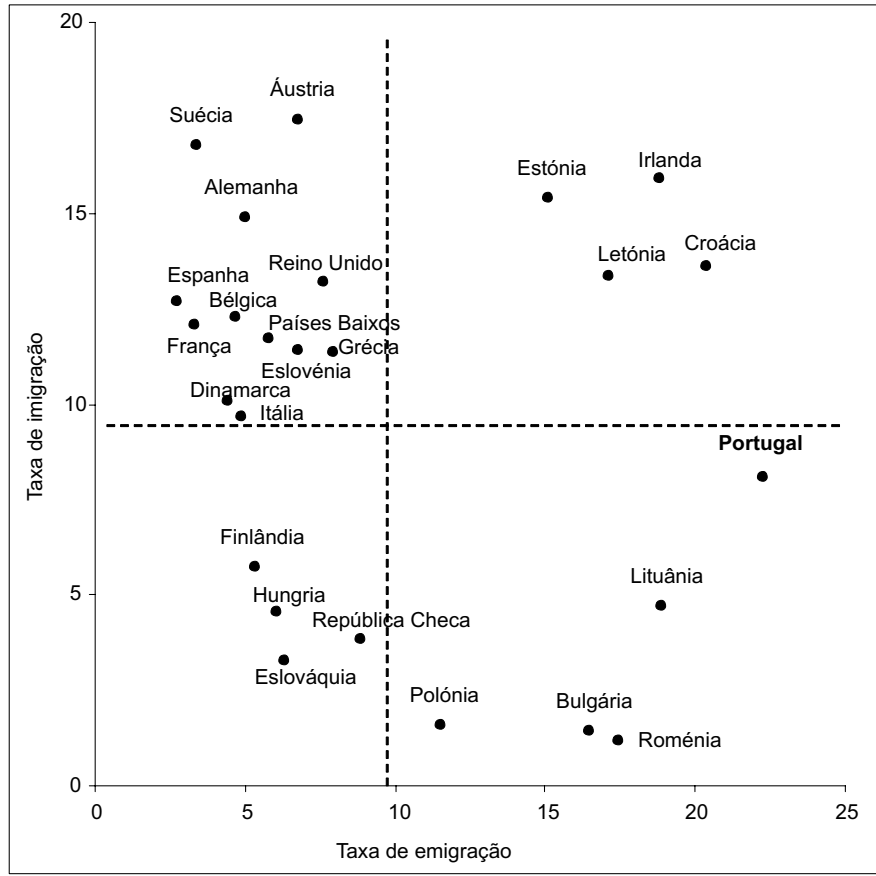

Figura 5 Taxas de emigração e de imigração nos países da União Europeia, 2015

Notas: apenas países com mais de um milhão de habitantes; taxa de emigração = número de emigrantes (stock) em percentagem da população do país de origem; taxa de imigração = número de imigrantes (stock) em percentagem da população do país de residência.

Fonte: cálculos do Observatório da Emigração, valores de United Nations, Department of Economic and Social Affairs, Population Division (2015), Trends in International Migrant Stock: Migrants by Destination and Origin (United Nations database, POP/DB/MIG/Stock/Rev.2015).

no conjunto dos países europeus de repulsão, quadrante onde, em 2015, se encontravam também a Lituânia, a Roménia, a Bulgária e a Polónia (ver figura 5).

Se, em termos de stock, Portugal era, em 2015, um país de repulsão, o mesmo se verificava em termos de fluxos. O que significa que, na segunda década do século XXI, a tendência foi a reprodução da posição repulsiva constituída ao longo do século XX. Para tal contribuiu tanto ou mais o baixo nível de imigração do que o alto nível de emigração. De facto, Portugal é um dos países da União Europeia com menos fluxos de imigração, mas não é, de acordo com os únicos dados que permitem uma comparação europeia, um país com elevadas taxas de emigração (saídas), em termos comparados. Fazendo uma média dos valores dos fluxos de entrada entre 2015 e 2017, só a Eslováquia apresentava uma taxa de entradas menor do que a de Portugal. ${ }^{17}$ Com valores da mesma ordem de grandeza, mas ligeiramente superiores, encontramos mais três países do Leste europeu: Croácia, Bulgária e República Checa. Já no que se refere às taxas de emigração de nacionais (saídas), Portugal situava-se, naquele mesmo período, a meio da tabela no espaço europeu. 
Portugal não tem apenas pouca imigração tanto em termos de stock como de fluxos. Nos anos de 2015-17, mais de metade dos fluxos de entrada deveram-se ao retorno de emigrantes (52\%). Ou seja, o regresso de emigrantes superou, nesse período, a imigração de estrangeiros. Na União Europeia, com maior percentagem de retorno de emigrantes nos fluxos de entrada, havia então outros seis países: Hungria, Letónia, Eslováquia, Croácia, Lituânia e Roménia. No mesmo patamar, com um valor para o retorno de nacionais ainda superior a $50 \%$ do fluxo de entrada, havia apenas mais um país, a Polónia. Ou seja, no domínio da imigração Portugal tem um perfil que o afasta tanto dos restantes países da Europa ocidental como, em menor grau, dos da orla do Mediterrâneo, assemelhando-se mais aos países do antigo bloco do Leste, caracterizados, ainda hoje, por grande imobilismo imigratório, embora com uma emigração em crescimento. Voltaremos a esta comparação.

Neste quadro, não admira que Portugal tenha acumulado saldos migratórios negativos nos anos em que a crise económica foi mais intensa, ou mesmo mais cedo. A diminuição do valor dos saldos negativos, desde 2015, e a eventual recuperação de saldos positivos, em 2017 e 2018, são, provavelmente, menos claras do que o expresso nas séries do Instituto Nacional de Estatística (INE), devido a limitações do instrumento de recolha de dados sobre a emigração utilizado por aquele instituto.

A análise dos problemas induzidos por essas limitações permite ilustrar algumas das questões metodológicas presentes no tratamento de dados estatísticos sobre as migrações internacionais, que resulta da existência de uma assimetria fundamental nas migrações internacionais, atualmente inversa daquela que a história conheceu até à I Guerra Mundial (Espírito-Santo, 2016: 9). O direito de sair do país em que se reside está hoje estabelecido, embora não seja assegurado universalmente. Pelo contrário, o direito de entrada num país continua a ser limitado pelo reconhecimento da soberania dos estados nacionais e do direito destes controlarem a entrada de estrangeiros no seu território. Não há, pois, registos de saídas (emigração) mas apenas de entradas (imigração). Por isso, a melhor forma de estudar a emigração de um país passa pela compilação de dados sobre a entrada e permanência dos seus emigrantes nos países de destino, assim se criando as chamadas "estatísticas espelho": os emigrantes de um país são estudados enquanto imigrantes nos destinos. Esta é a orientação recomendada pelas Nações Unidas (United Nations Economic Commission for Europe, 2011: 75) e seguida por organismos internacionais como o Banco Mundial ou a OCDE. E é, também, a orientação seguida pelo Observatório da Emigração, que compila, disponibiliza e analisa estatísticas sobre os imigrantes portugueses nos países de destino da emigração. Porém, a opção das autoridades estatísticas europeias para conhecer a emigração foi diferente. Os dados compilados e divulgados pelo Eurostat sobre emigração e imigração nos estados-membros são produzidos pelos institutos de estatística nacionais mobilizando procedimentos muito diversos: uso de fontes administrativas (o método mais usado), inquéritos por amostragem, dados censitários, estatísticas espelho (o

17 Taxa bruta de saídas (emigração) = saídas num ano em percentagem da população residente no país de origem nesse mesmo ano. Taxa bruta de entradas (imigração) = entradas num ano em percentagem da população residente no país de destino nesse mesmo ano. 
método usado por menos países), modelos matemáticos de estimação ou uma combinação de várias fontes. ${ }^{18}$

No caso português, o INE recorre a um processo de inquirição por amostragem, associado à aplicação do Inquérito ao Emprego, para estimar a emigração total anual. A operação de inquirição é indireta, pois quem saiu não pode, por definição, ser inquirido no sítio de onde saiu. São os residentes que são interrogados sobre quem conhecem que tenha saído, bem como sobre as intenções daqueles relativamente ao tempo de permanência no exterior (em rigor, uma opinião sobre intenções de terceiros). As limitações deste processo de inquirição no domínio dos fluxos de emigração, mas não tanto dos de imigração, em que a inquirição é direta, tem-se traduzido numa sistemática subavaliação dos números da emigração permanente pelo INE. De acordo com os dados compilados pelo Observatório da Emigração, a partir das estatísticas das entradas de portugueses nos países de destino, essa subavaliação é, em média, desde 2010, da ordem dos $40 \%$. Porém, o mesmo não se passa no caso dos dados da imigração, mais fiáveis por duas ordens de razões: inquirição direta e possibilidade, pelo menos potencial, de acerto com recurso a fontes administrativas. Resultado: a inversão do saldo migratório em 2017 e 2018, que de acordo com o INE passou a ser positivo, poderá ser menor do que o estimado por aquele organismo, ou mesmo não ter ainda acontecido, permanecendo o saldo negativo, embora em menor grau do que em anos anteriores.

Note-se que os valores dos saldos estimados pelo INE incluem o efeito do retorno de emigrantes portugueses, contabilizados pelo organismo estatístico nacional, corretamente, como entradas de imigrantes em Portugal. ${ }^{19}$ Sem esse efeito, o saldo migratório português seria negativamente agravado. De acordo com os dados do INE/Eurostat, no período 2015-17, o saldo migratório português teve um valor médio anual negativo de -4648 indivíduos, que passaria para -20 602 se descontados os movimentos de retorno. Sem estes movimentos, o valor observado para o saldo migratório colocava Portugal entre o grupo dos países europeus com uma dinâmica migratória mais repulsiva. Uma vez mais, esse grupo é constituído quase só por países do Leste europeu. O saldo migratório, no caso português, excluindo os movimentos de retorno, e medido em percentagem da população do país, foi, em média, entre 2015 e 2017, de -0,20\%. Em termos relativos, só havia na União Europeia quatro países com saldos migratórios ainda mais negativos: Letónia, Croácia, Roménia e Lituânia. E com valores um pouco menos negativos, mas ainda da mesma ordem de grandeza, mais dois países do Leste: Polónia e Bulgária (ver figura 6).

Os movimentos de retorno que temos vindo a referir são de dois tipos. Nos fluxos de imigração, têm como indicador a entrada, nos países de origem, num determinado ano, de nacionais desses países, por exemplo, a entrada de portugueses em

18 Apesar das limitações que resultam da diversidade de métodos usados por cada estado-membro, usam-se nesta secção os dados do Eurostat, por duas razões: são os únicos que permitem uma comparação internacional com um mínimo de harmonização (pelo menos no plano das definições das variáveis e das populações); e são os únicos dados disponíveis sobre retornos com periodicidade anual.

19 As Estimativas Anuais de Imigração do Instituto Nacional de Estatísticas (INE) são a principal fonte estatística nacional sobre retorno de imigrantes, em termos agregados. 


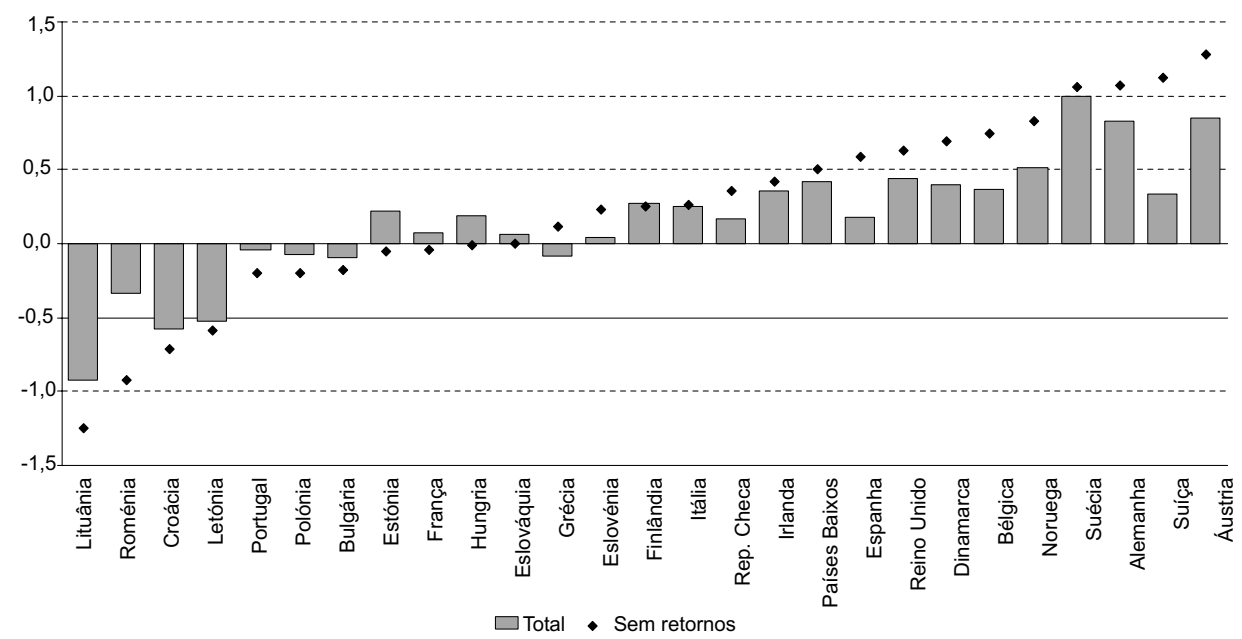

Figura 6 Saldos migratórios relativos, países da União Europeia e EFTA, média 2015-2017

Notas: apenas países com mais de um milhão de habitantes; saldos migratórios relativos = entradas menos saídas (fluxos) em percentagem da população residente; saldos migratórios relativos sem retornos = entradas de estrangeiros menos saídas de nacionais (fluxos), em percentagem da população residente.

Fonte: cálculos do Observatório a partir dos dados do Eurostat.

Portugal. Nos fluxos de emigração, considera-se como movimento de retorno a saída de estrangeiros do país de residência, por exemplo, a saída de estrangeiros a viver em Portugal num determinado ano. ${ }^{20} \mathrm{~A}$ análise desses fluxos permite perceber melhor as características variáveis dos processos transnacionais nas migrações internacionais, que incluem o conjunto de laços entre países de origem e destino dessas migrações, suportados pela criação de espaços transnacionais constituídos pela circulação dos migrantes (Faist, Fauser e Reisenauer, 2013).

Ora, a importância relativa dos movimentos de retorno na emigração e na imigração é muitas vezes assimétrica. No caso europeu, os dados disponíveis para o período em análise (2015-17) revelam a existência de dois blocos definidos por essa assimetria. O primeiro, constituído quase só por países do antigo Leste europeu, em que se insere ainda Portugal, é caracterizado por uma elevada percentagem de retorno de emigrantes ao país de origem nos fluxos de entrada e uma baixa, ou muito baixa, percentagem do retorno de imigrantes estrangeiros a viver no país, nos fluxos de saída. No outro bloco, o peso relativo de nacionais e estrangeiros nos fluxos de entrada e saída é inverso: menor percentagem de retorno de nacionais nos fluxos de imigração e percentagem elevada de retorno de estrangeiros nos fluxos de emigração. Neste segundo bloco estavam, no período em análise, países do Norte e Sul da Europa, mas quase nenhum país do Leste, à exceção da República Checa e da Eslovénia (ver figura 7).

20 Em rigor estas saídas tanto podem ser de retorno ao país de origem como de re-emigração para um terceiro país. Porém, para os efeitos da argumentação nesta secção, a especificação pode ser dispensada. 


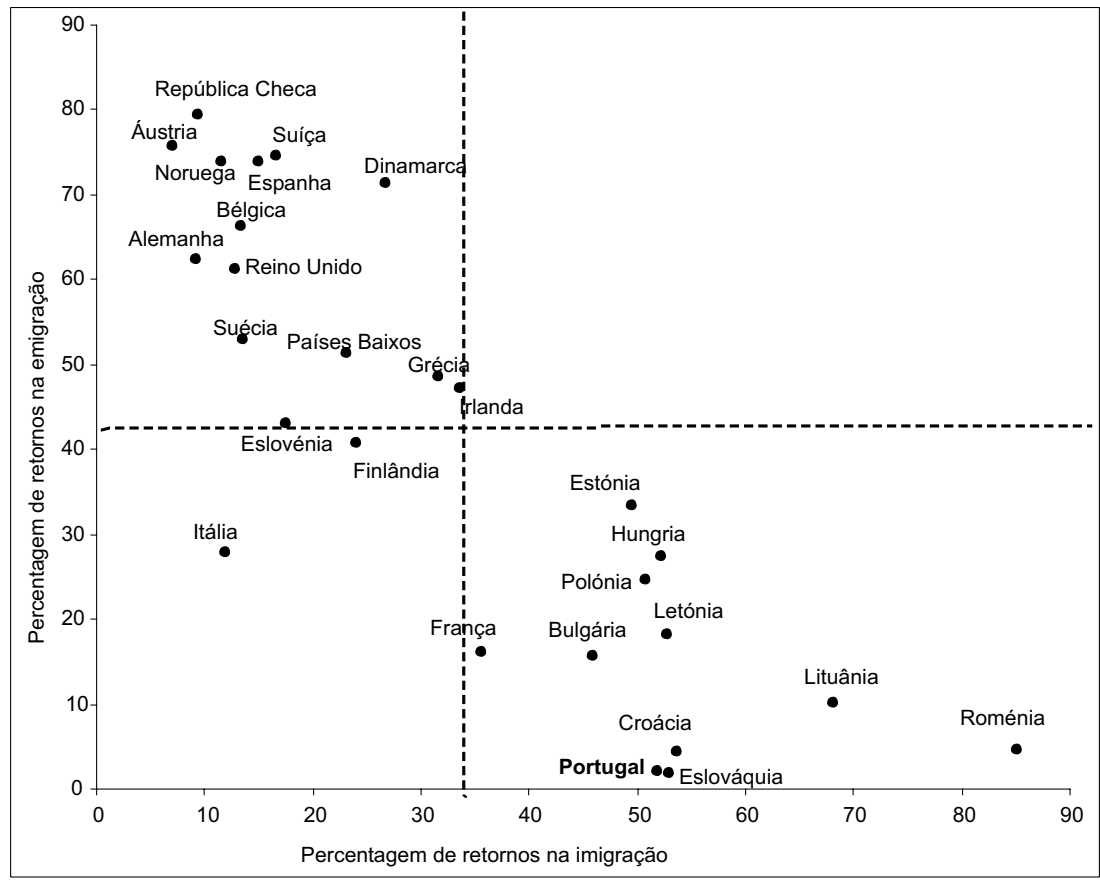

Figura 7 Retornos nas migrações, países da União Europeia e EFTA, média 2015-2017

Notas: apenas países com mais de um milhão de habitantes; retornos na emigração = entradas de nacionais em percentagem das entradas totais; retornos na imigração = saídas de estrangeiros em percentagem das saídas totais Fonte: cálculos a partir dos dados do Eurostat.

Ou seja, nos países do primeiro bloco (países do Leste e Portugal), a criação de espaços transnacionais faz-se sobretudo com base na emigração e só marginalmente com base na imigração. Nos países do segundo bloco esses espaços são, pelo contrário, constituídos predominantemente no âmbito dos processos de imigração. O primeiro tipo de espaços transnacionais será mais instrumental, do ponto de vista da relação entre migrações e desenvolvimento, mas menos cosmopolita do que o segundo, podendo mesmo ser definido, paradoxalmente, como espaço transnacional localista, para retomar, em termos um pouco livres e alargados, a oposição mertoniana entre cosmopolitas e locais (Merton, 1970 [1968]: 479-513). Esta é, no entanto, uma tipologia ainda provisória, sendo necessário analisar um pouco melhor o volume absoluto e relativo dos movimentos de retorno, bem como a sua composição sociodemográfica, para poder afinar, e eventualmente desdobrar, aquelas duas categorias.

É sobretudo neste sentido que se pode falar na inserção de Portugal no anel do Leste mais do que na periferia Sul da Europa. Noutros domínios, fará sentido falar de Portugal como um país do Sul em termos migratórios. Desde logo porque partilha com os outros países do Sul um tempo mais precoce de abertura à imigração, desde os anos 70/80 do século XX, embora se distinga dos mesmos por uma menor amplitude 
daqueles fluxos imigratórios. Em segundo lugar, porque partilha com os países da periferia sul um modo de incorporação dos imigrantes em que a existência de um mercado de trabalho informal tem um papel decisivo na sua integração num contexto de frequente irregularidade do estatuto de fixação (King, 2000).

Porém, no plano do volume, composição e saldo dos movimentos migratórios, a proximidade com o arco leste-europeu predominou ao longo da segunda década do século XXI. É este posicionamento conjuntural? Um indicador mais estrutural remete para uma resposta provisoriamente negativa a esta pergunta. Como já foi referido, em termos de stocks migratórios, ou seja, em resultado da acumulação longa na história recente de processos de fixação de emigrantes e imigrantes, Portugal partilha também um espaço em que só tem por companhia países do arco leste-europeu: países que, como Portugal, têm, em proporção da sua população residente, elevado número de emigrados e baixo número de imigrantes. Com este histórico, seria necessária uma inversão continuada no volume e composição dos fluxos migratórios de e para Portugal para que o país visse alterado o seu posicionamento no espaço europeu.

\section{Referências bibliográficas}

Baganha, Maria Ioannis, e José Carlos Marques (2001), “População", em Nuno Valério (org.), Estatísticas Históricas Portuguesas, vol. I, Lisboa, Instituto Nacional de Estatística, pp. 33-126.

Blau, Peter M. (1977), Inequality and Heterogeneity. A Primitive Theory of Social Structure, Nova Iorque, The Free Press.

Candeias, Pedro (2017), "Alemanha", OEm Country Reports, 4, Observatório da Emigração, CIES-IUL, ISCTE-IUL, DOI: 10.15847/CIESOEMFS042017.

Cândido, Ana Filipa (2018), "Portuguese skilled migration in DIOC 2010/11", OEm Fact Sheets, 8, Observatório da Emigração, CIES-IUL, ISCTE-IUL, DOI: $10.15847 /$ CIESOEMFS082018.

Castelo, Cláudia (2007), Passagens para África. O Povoamento de Angola e Moçambique com Naturais da Metrópole (1920-1974), Porto, Afrontamento.

Castles, Stephen, Hein De Haas, e Mark J. Miller (2014), The Age of Migration. International Population Movements in the Modern World, Basingstoke (Hampshire), Palgrave Macmillan (5. ․ edição).

de Haas, Hein (2010), “The internal dynamics of migration processes: a theoretical inquiry", Journal of Ethnic and Migration Studies, 36 (10), pp. 1587-1617.

Demeulenaere, Pierre (2011), "Causal regularities, action and explanation", em Pierre Demeulenaere (org.), Analytical Sociology and Social Mechanisms, Cambridge, Cambridge University Press.

Espírito-Santo, Inês (2016), “Politique et migration: entretien avec Catherine Wihtol de Wenden", OEm Conversations With, 2, Lisboa, Observatório da Emigração, CIES-IUL, ISCTE-IUL.

Espírito-Santo, Inês, e Cláudia Pereira (2015), “18 mil portugueses emigraram para França em 2012", Observatório da Emigração, disponível em: http://observatorioemigracao.pt/np4/4276.html 
Faist, Thomas (2000), The Volume and Dynamics of International Migration and Transnational Social Spaces, Oxford, Oxford University Press.

Faist, Thomas, Margit Fauser, e Eveline Reisenauer (2013), Transnational Migration, Cambridge, Polity Press.

Giddens, Anthony (1984), The Constitution of Society. Outline of the Theory of Structuration, Cambridge, Polity Press.

Giddens, Anthony (1994 [1991]), Modernidade e Identidade Pessoal, Oeiras, Celta.

Góis, Pedro, José Carlos Marques, Pedro Candeias, Bárbara Ferreira, e Alexandra Ferro (2016), "Novos destinos migratórios: a emigração portuguesa para o Reino Unido", em João Peixoto et al. (orgs.) (2016), Regresso ao Futuro. A Nova Emigração e a Sociedade Portuguesa, Lisboa, Gradiva, pp. 71-106.

Goldin, Ian, Geoffrey Cameron, e Meera Blarajan (2011), Exceptional People. How Migration Shaped Our World and Will Define Our Future, Princeton, Princeton University Press.

Gomes, Rui Machado (2015a), “Uma visão macroscópica da emigração qualificada: respostas a perguntas frequentes", em Rui Machado Gomes (coord.), Fuga de Cérebros, Lisboa, Bertand, pp. 17-30.

Gomes, Rui Machado (coord.) (2015b), Fuga de Cérebros, Lisboa, Bertand.

Hirschman, Albert O. (1970), Exit, Voice, and Loyalty. Responses to Decline in Firms, Organizations, and States, Cambridge, MA, Harvard University Press.

Justino, David (2016), Emigration from Portugal. Old Wine in New Bottles?, Washington, DC, Migration Policy Institute, disponível em: www.migrationpolicy.org/research/emigration-portugal-old-wine-new-bottles

King, Russell (2000), "Southern Europe in the changing global map of migration”, em Russell King, Gabriella Lazaridis e Charalambos Tsadanidis (orgs.), Eldorado or Fortress? Migration in Southern Europe, Basingstoke (Hampshire), Macmillan, pp. 3-26.

Lopes, João Teixeira (2014), Geração Europa? Um Estudo sobre a Jovem Emigracão Qualificada para França, Lisboa, Mundos Sociais.

Lourtie, Pedro (2011), "Portugal no contexto da crise do euro", Relações Internacionais, 32, pp. 61-105, disponível em: www.scielo.mec.pt/scielo.php?script=sci_arttext\&pid= S1645-91992011000400005\&lng=pt\&nrm=iso

Marques, José Carlos (2016), "Suíça”, OEm Country Reports, 3, Lisboa, Observatório da Emigração, CIES-IUL, ISCTE-IUL, DOI: 10.15847/CIESOEMCR032016.

Marques, José Carlos, Pedro Góis, Pedro Candeias, Bárbara Ferreira, e Alexandra Ferro (2016), "A emigração recente de portugueses para França", em João Peixoto et al. (orgs.), Regresso ao Futuro: A Nova Emigração e a Sociedade Portuguesa, Lisboa, Gradiva, pp. 109-139.

Massey, Douglas S., Joaquin Arango, Graeme Hugo, Ali Kouaouci, Adela Pellegrino, e J. Edward Taylor (1993), “Theories of international migration: a review and appraisal", Population and Development Review, 19 (3), pp. 431-466.

Merton, Robert K. (1970 [1968]), Sociologia. Teoria e Estrutura, São Paulo, Mestre Jou.

Myrdal, Gunnar (1957), Rich Lands and Poor. The Road to World Prosperity, Nova Iorque, Harper \& Row.

Observatório da Emigração (2015), Portuguese Emigration Factbook 2015, Lisboa, Observatório da Emigração, CIES-IUL, ISCTE-IUL, DOI: 10.15847/CIESOEMFB2015.

OECD (2011), International Migration Outlook 2011, Paris, OECD Publishing, DOI: 10.1787/migr_outlook-2011-en. 
Peixoto, João (2000), “A emigração”, em Francisco Bethencourt e Kirti Chaudhuri (orgs.), História da Expansão Portuguesa, vol. 5: Último Império e Recentramento (1930-1998), Lisboa, Temas e Debates, pp. 152-181 e 212-213.

Peixoto, João, Isabel Tiago de Oliveira, Joana Azevedo, José Carlos Marques, Pedro Góis, Jorge Malheiros, e Paulo Miguel Madeira (orgs.) (2016), Regresso ao Futuro. A Nova Emigração e a Sociedade Portuguesa, Lisboa, Gradiva.

Pereira, Cláudia (2015), Vidas Partidas. Enfermeiros Portugueses no Estrangeiro, Loures, Lusodidacta.

Pereira, Cláudia, e Joana Azevedo (2019a), “The fourth wave of Portuguese emigration: austerity policies, European peripheries and postcolonial continuities", em Cláudia Pereira e Joana Azevedo (orgs.), New and Old Routes of Portuguese Emigration, IMISCOE Research Series, Cham, Springer International Publishing, pp. 1-26, DOI: https://doi.org/10.1007/978-3-030-15134-8_1.

Pereira, Cláudia, e Joana Azevedo (2019b), New and Old Routes of Portuguese Emigration, IMISCOE Research Series, Cham, Springer International Publishing, DOI: 10.1007/978-3-030-15134-8.

Pereira, Cláudia, Nuno Pinto, e Rui Pena Pires (2015), “Portuguese nurses in the UK 2014", OEm Fact Sheets, 3, Observatório da Emigração, CIES-IUL, ISCTE-IUL, DOI: 10.15847/CIESOEMFS032015-pt-en.

Pinho, Filipa, e Rui Pena Pires (2013), “Espanha”, OEm Country Reports, 1, Observatório da Emigração, CIES-IUL, ISCTE-IUL, DOI: 10.15847/CIESOEMCR012013.

Pires, Rui Pena (2003), Migrações e Integração. Teoria e Aplicações à Sociedade Portuguesa, Oeiras, Celta.

Pires, Rui Pena (2015), “Modos de explicação”, Sociologia, Problemas e Práticas, 78, pp. 125-141.

Pires, Rui Pena (2019), “Portuguese emigration today”, em Cláudia Pereira e Joana Azevedo (orgs.), New and Old Routes of Portuguese Emigration, IMISCOE Research Series, Cham, Springer International Publishing, pp. 29-48, DOI: 10.1007/978-3-030-15134-8_2.

Pires, Rui Pena, Cláudia Pereira, Joana Azevedo, e Ana Cristina Ribeiro (2014), Emigração Portuguesa. Relatório Estatístico 2014, Lisboa, Observatório da Emigração e Rede Migra, CIES-IUL, ISCTE-IUL, DOI: 10.15847/CIESOEMRE012014.

Pires, Rui Pena, Cláudia Pereira, Joana Azevedo, Inês Espírito Santo, Inês Vidigal, e Ana Cristina Ribeiro (2015), Emigração Portuguesa. Relatório Estatístico 2015, Lisboa, Observatório da Emigração e Rede Migra, CIES-IUL, ISCTE-IUL e DGACCP.

Pires, Rui Pena, e Cláudia Pereira (2018), “Migrações, qualificações e desigualdade social", em Renato Miguel do Carmo et al. (orgs.), Desigualdades Sociais. Portugal e a Europa, Lisboa, Mundos Sociais, pp. 335-352.

Pires, Rui Pena, e Inês Espírito-Santo (2016), “Saldos migratórios 2000-2013”, OEm Fact Sheets, 4, Observatório da Emigração, CIES-IUL, ISCTE-IUL, DOI: 10.15847/CIESOEMFS042016.

Pires, Rui Pena, Joana Azevedo, Inês Vidigal, e Carlota Moura Veiga (2019), Emigração Portuguesa. Relatório Estatístico 2019, Lisboa, Observatório da Emigração e Rede Migra, CIES-IUL, ISCTE-IUL.

Portes, Alejandro (1999), Migrações Internacionais. Origens, Tipos e Modos de Incorporação, Oeiras, Celta.

Tiebout, Charles M. (1956), "A pure theory of local expenditures”, The Journal of Political Economy, 64 (5), pp. 416-424. 
United Nations Development Programme (2019), Human Development Report 2019. Beyond Income, Beyond Averages, Beyond Today: Inequalities in Human Development in the 21st Century, Nova Iorque, UNDP, disponível em: http://hdr.undp.org/sites/default/files/hdr2019.pdf

United Nations Economic Commission for Europe (2011), Statistics on International Migration. A Practical Guide for Countries of Eastern Europe and Central Asia, Genebra, UNECE, disponível em: www.unece.org/index.php?id=27236

Vidigal, Inês (2018), “Emigração portuguesa para o Canadá, 1966-2016", OEm Fact Sheets, 7, Observatório da Emigração, CIES-IUL, ISCTE-IUL, DOI: 10.15847/CIESOEMFS072018.

Vidigal, Inês (2020), "Aumento de última hora na emigração para o Reino Unido", Observatório da Emigração, disponível em: http://observatorioemigracao.pt/np4/7345.html

Vidigal, Inês, e Rui Pena Pires (2018), "Brexit”, Observatório da Emigração, disponível em: http://observatorioemigracao.pt/np4/5988.html

Weber, Max (1949 [1905]), "Critical studies in the logic of the cultural sciences", em Max Weber, The Methodology of Social Sciences, Nova Iorque, The Free Press, pp. 113-188 (ensaios selecionados e traduzidos por Edward A. Shils e Henry A. Finch).

Wihtol de Wenden, Catherine (2018), Atlas des Migrations: Un Equilibre Mondial à Inventer, Paris, Autrement (5. edição).

Rui Pena Pires. Professor no Iscte - Instituto Universitário de Lisboa, e investigador no Centro de Investigação e Estudos de Sociologia (CIES-Iscte), Lisboa, Portugal. E-mail: rui.pires@iscte-iul.pt

Cláudia Pereira. Investigadora no Centro de Investigação e Estudos de Sociologia (CIES-Iscte), Iscte - Instituto Universitário de Lisboa, Lisboa, Portugal.

E-mail: claudia.pereira@iscte-iul.pt

Joana Azevedo. Professora no Iscte - Instituto Universitário de Lisboa, e investigadora no Centro de Investigação e Estudos de Sociologia (CIES-Iscte), Lisboa, Portugal. E-mail: joana.azevedo@iscte-iul.pt

Inês Vidigal. Assistente de investigação no Centro de Investigação e Estudos de Sociologia (CIES-Iscte), Iscte - Instituto Universitário de Lisboa, Lisboa, Portugal. E-mail: ines.vidigal@iscte-iul.pt

Carlota Moura Veiga. Assistente de investigação no Centro de Investigação e Estudos de Sociologia (CIES-Iscte), Iscte - Instituto Universitário de Lisboa, Lisboa, Portugal. E-mail: carlota.veiga@iscte-iul.pt

Receção: 27 de fevereiro de 2020 Aprovação: 17 de março de 2020 